\title{
Modelling of oxygen and nitrogen cycling as a function of macrophyte community in the Thau lagoon
}

\author{
Martin Plus ${ }^{a}$, Annie Chapelle $^{b}$, Alain Ménesguen $^{\mathrm{b}}$, Jean-Marc Deslous-Paolic $^{\mathrm{c}}$, Isabelle Auby ${ }^{\mathrm{d}}$
}

\author{
a European Commission, JRC, Institute for Environment and Sustainability, Inland and Marine Waters Unit, TP \\ 280. 21020-Ispra (VA), Italy \\ ${ }^{b}$ Département IFREMER DEL/EC, B.P. 70, 29280 Plouzané, France \\ ${ }^{\mathrm{c}}$ Laboratoire IFREMER DRV/RA, Chemin de Maguelone, 34250 Palavas-les-Flots, France \\ d Laboratoire IFREMER DEL/AR, Quai du Commandant Silhouette, 33120 Arcachon, France \\ *: Corresponding author : Martin.Plus@ifremer.fr
}

\begin{abstract}
:
A three-dimensional model coupling physical and biological processes for the whole Thau lagoon (Mediterranean coast of France) was developed in order to assess the relationships between macrophytes and the oxygen and nitrogen cycles. Ten species have been inserted as forcing variables in the model. Plankton dynamics, shellfish cultivation impact and mineralization of organic matter are also considered, as well as nutrient and oxygen exchanges between the sediment and the water column.

Simulations with and without the macrophytes have shown that the system can be characterized as having a highly structured pattern involving lagoon nitrogen and oxygen cycles. This pattern is created by the combined influence of macrophytes, watershed and oyster farming.

The model has been also used to assess the total annual macrophyte production at the whole lagoon scale. Comparisons with phytoplankton production and with results from other temperate lagoons have underlined the high productivity of the Thau lagoon supported by active nutrient regeneration.
\end{abstract}

Keywords: Macrophytes; Ecological modelling; Biogeochemical cycles; Thau lagoon 


\section{Introduction}

In shallow coastal ecosystems, macrophytes account for high biomasses and productivity (Sand-Jensen, 1975, Short, 1987, Knoppers, 1994, Viaroli et al., 1996), sustain the food chain (Newel, 1982, Grias, 1992, Gerbal and Verlaque, 1995), and control the nearshore nutrient cycles (Sfriso et al., 1989, Ménesguen, 1992, Carreira et al., 1994, Ménesguen and Piriou, 1995, Touchette and Burkholder, 2000).

The shallow Thau lagoon is $15 \mathrm{~km}$ long, $5 \mathrm{~km}$ wide and on average $4 \mathrm{~m}$ deep. It is located on the French Mediterranean coast (figure 1) and is sheltered with two narrow sea mouths. The catchment area is small $\left(280 \mathrm{~km}^{2}\right)$ and drained by numerous small streams with intermittent flows. The climate imposes a wide range of water temperatures and salinities with minima of $5^{\circ} \mathrm{C}$ in February and salinity near 27, and maxima of $29^{\circ} \mathrm{C}$ in August and a salinity of 40. Precipitation also shows large interannual variation (from 200 to $1000 \mathrm{~mm}$ per year). Wind is often strong with a mean of 118.5 days per year above Beaufort force 5 (data from Météo-France), particularly when it is blowing from the Northwest (the so called « Tramontane »). Both play an important role in the lagoon hydrodynamics (Lazure 1992). Besides its ecological interest as a recruitment zone for some sea fish species, the lagoon is of notable economic importance due to shellfish cultivation (about 15000 tons per year, amongst the highest in the Mediterranean Sea). The Thau lagoon frequently undergoes, in summer, anoxia that can lead to important economic losses. For example in august 1997, nearly one third of the annual oyster annual production was lost.

During the last fifteen years, the Thau lagoon has been extensively studied, with investigations of the exchange between the water column and sediments, the oysters farming activities, the impact of the watershed and interactions with the Mediterranean sea (Amanieu et al., 1989, Picot et al., 1990, Pichot et al., 1994, Deslous-Paoli, 1995, and references therein). Various numerical models have been developed, focusing on hydrodynamics 
(Lazure, 1992), nitrogen and oxygen cycles (Chapelle, 1995; Chapelle et al., 2001), plankton ecosystem (Chapelle et al., 2000), impact of shellfish farming (Bacher et al., 1997). Nonetheless, the macrophyte compartment has not been, until now, included in these models.

The aim of this study is to develop a model that assesses the impact of macrophytes on the nitrogen and oxygen cycles. In order to assess the macrophyte impact on the biogeochemical cycles at a small spatial scale and to cope with the water column vertical heterogeneity (phytoplankton is distributed within the water column while macrophytes are on the bottom, in contact with the sediment), it was decided to use a three-dimensional model.

\section{Materials and methods}

\subsection{Model description}

The macrophyte model has been developed and coupled with the three-dimensional hydrodynamical-biological model of the Thau lagoon (Lazure, 1992, Chapelle et al., 2001).

The hydrodynamical model solves three-dimensional equations under the classical hydrostatic, heat and salt conservation hypothesis (Lazure, 1992). The model considers ten strata of different thickness (depending on depth) along the vertical, and $400 \mathrm{~m}$ regular squared meshes on the horizontal scale. The bathymetric maps of the SHOM ("Service Hydrographique de la Marine Nationale") were used and water exchange with the Mediterranean Sea (Sète canals) was taken into account.

Figure 2 gives the general conceptual diagram of the biological model. For this study, the classification of phytoplankton and zooplankton variables into two size classes, as carried out by Chapelle et al. (2000), was not necessary as plankton dynamics was not the aim of this study. Therefore, in order to simplify the model, we reduced the number of state variables, grouping pico-nanophytoplankton with microphytoplankton on one hand and microzooplankton with mezozooplankton on the other. Seven state variables were considered: 
ammonia, nitrates, phytoplankton, zooplankton, detritus, oyster biodeposits and oxygen. The model is based on nitrogen since it has been found to be the limiting nutrient in the Thau lagoon (Picot et al., 1990). Dissolved oxygen has also been considered in order to simulate photosynthesis, respiration and mineralization processes. Forcing variables are nitrogen inputs from watershed, light, water temperature, wind, oyster farming and macrophyte community. Table 1 presents all equations and parameters differing from Chapelle et al. (2000) due to the simplification of plankton food web. All other equations and parameters linked to detritus mineralization, nitrogen nitrification and denitrification as well as oysters filtration and excretion remained unchanged, please refer to Chapelle et al. (2000) for a detailed description.

\section{Macrophyte communities:}

Several studies on the Thau lagoon flora have already been performed and allow a good description of macrophyte communities. Total macrophyte biomass was estimated as 10 $073 \pm 2006$ tons dry weight in autumn 1986 (Gerbal, 1994; Gerbal and Verlaque, 1995) and, until now, a total of 196 different macroalgae taxa has been recorded (Verlaque, 2001).

During May and June 1998, within the framework of the French National Program for Coastal Environment (PNEC), a re-evaluation of the macrophyte community (distribution and biomass) was carried out in the Thau lagoon. Sampled stations are reported on Figure 1. The campaign results have been used as a basis for the model. In order not to give too much importance to species with very low biomasses, we only kept in the model species with biomasses higher than one percent of the total macrophyte biomass. Following this criterion, ten species, accounting for $93 \%$ of total biomass, were selected (Table 2). The biomass data were processed with a Correspondence Analysis (CA) in order to represent the spatial structure of the macrophyte community and identify areas with a homogeneous macrophyte 
association. All statistical analyses were performed with S-PLUS 4 software (Splus, 1997), using no-transformed data. In summary seven zones were identified (Figure 3):

$\diamond$ Zone 1 is the west extremity of the Thau lagoon, including the shellfish area C. Hi, Rt and $\mathrm{Zm}$ are the dominant species. This zone accounts for $38 \%$ of the total fresh biomass of the lagoon.

$\diamond$ Zone 2 includes stations 1.1, 2.1 and 3.1. This zone is shallow with a monospecific seagrass meadow $(\mathrm{Zn})$.

$\diamond$ Zone 3 includes the entire shellfish area B and the north border up to the village of Mèze. The macrophyte community is considered monospecific with $\mathrm{Zm}$ accounting for $91 \%$ of the total biomass of this zone.

$\diamond$ Zone 4 is located all along the narrow sandy strand which separates the lagoon from the Mediterranean Sea (the Lido). This sector is covered by mixed seagrass meadows ( $\mathrm{Zm} 20 \%$ and $\mathrm{Zn} 80 \%$ ).

$\diamond$ Zone 5 has the highest specific diversity. Four dominant species $G c, G c, G l$ and $C l$, accounting for $80 \%$ of the total biomass of this area were selected.

$\diamond$ Zone 6, located near Sète, is characterised by Gc, Gl and the two opportunistic Ulvaceans Ur and Mo. These four species account for $90 \%$ of the biomass of this sector.

$\diamond$ The central deeper zone 7 (depth $>7 \mathrm{~m}$ ) is macrophyte free and dominated by phytoplankton.

The initial biomasses assigned to each model mesh were obtained from the zonation of the lagoon (Table 3, and Figure 3). A fixed height for each species was empirically defined in order to distribute the biomass in the vertical plan. Furthermore, with the aim of taking into account the sediment processes, an additional layer $(20 \mathrm{~cm}$ deep) has been added on the bottom. Then, for each mesh containing phanerogams, a belowground biomass has been 
assigned to the sediment layer. This biomass equals $80 \%$ of aboveground biomass for Zostera marina and $50 \%$ for Zostera noltii (Plus, 2001).

Since the measurement campaign was performed during summer, measured biomass was taken as annual peak, and winter biomass was considered to be about $50 \%$ of the summer maximum (Gerbal, 1994). A sinusoidal was obtained by fitting those measured data, and used to calculate the biomass as a function of time: winter minimum in January and summer maximum, 12039 tons dry weight, in July.

\section{Macrophyte photosynthesis:}

The tangential hyperbolic P/I curve from Jassby and Platt (1976) was used to simulate macrophyte photosynthesis. The gross production rate $\left(\mathrm{GP}, \mathrm{gO}_{2} \cdot \mathrm{gDW}^{-1} \cdot \mathrm{d}^{-1}\right)$ was then calculated using equation (1):

$$
G P=P_{\max } \times \tanh \left(\frac{I_{z}}{I_{k}}\right)
$$

with Pmax, the maximum production rate $\left(\mathrm{gO}_{2} \cdot \mathrm{gDW}^{-1} \cdot \mathrm{d}^{-1}\right)$, Iz the incoming light at depth $\mathrm{z}$ (m) and $I_{k}$, the saturation light coefficient $\left(\mu \mathrm{mol}\right.$ photons. $\left.\mathrm{m}^{-2} \cdot \mathrm{s}^{-1}\right)$. Parameters Pmax, dependent on temperature, and Ik, annual mean, are presented in Table 4 and come from polarographic measurements (see methods in Henley et al., 1991 and Simon et al., 1999) performed on macrophytes sampled in the Thau lagoon (courtesy by Auby and Levavasseur). When parameters could not be obtained ( $G l$ and $R t$ ), the relationship found for similar algae species was applied. For instance, the $\mathrm{I}_{\mathrm{k}}$ value and $\mathrm{P}_{\max }$ equation for $G l$ and $R t$ were taken from $\mathrm{Gc}$ and $\mathrm{Hi}$ respectively. $\mathrm{I}_{\mathrm{z}}$ was calculated according to a classical Beer-Lambert exponential attenuation function of the incident light at the water surface. The macrophyte gross production $\left(\mathrm{GP}_{\mathrm{mac}}, \mathrm{gO}_{2} \cdot \mathrm{m}^{-3} \cdot \mathrm{d}^{-1}\right)$ was derived from equation (1), according to the following equation:

$$
G P_{\text {mac }}=G P \times \lim (N) \times B
$$


where $\mathrm{B}$ is the macrophyte biomass $\left(\mathrm{gDW} \cdot \mathrm{m}^{-3}\right)$ and $\lim (\mathrm{N})$, the effect of nitrogen (dimensionless) on production. In order to lower primary production when nitrogen concentrations are low, a limitation function based on nitrogen was added to the production calculation. The Wroblewski (1980) formula (equation 3 to 5) was chosen to take also into account the preference of macrophytes for ammonium or nitrate (Iizumi and Hattori, 1982, Thursby and Harlin, 1982, Short and Mc Roy, 1984). In addition, a second nitrogen limitation function was calculated for seagrasses, considering the nitrogen uptake from sediment. This nitrogen limiting function is based only on ammonium concentration, since reducing conditions keep nitrate at very low concentrations in the sediment (Chapelle, 1995). In summary:

1) for all macroalgae species (Hi, Rt, Gc, Gd, Gl, Cl, Ur and Mo):

$$
\lim (\mathrm{N})=\lim \left(\mathrm{NH}_{4}^{+}\right)_{\text {wat }}+\lim \left(\mathrm{NO}_{3}^{-}\right)_{\text {wat }}
$$

with,

$\lim \left(N H^{+}\right)_{\text {wat }}=\frac{N H_{4 \text { wat }}^{+}}{N H_{4 \text { wat }}^{+}+K_{N}} \quad(4) ; \lim \left(N O_{3}^{-}\right)_{\text {wat }}=\frac{N O_{3_{\text {wat }}^{-}}}{N O_{3_{\text {wat }}^{-}}+K_{N}} \times e^{\left(-\Psi \times N O_{3_{\text {wat }}^{-}}\right)}$

where $\mathrm{NH}_{4 \text { wat }}^{+}$and $\mathrm{NO}_{3 \text { wat }}^{-}$represent the ammonium and nitrates concentrations in the water column (mmolN.m $\left.{ }^{-3}\right), \mathrm{K}_{\mathrm{N}}$ is the half-saturation coefficient for the water column (4 mmolN.m ${ }^{-3}$, Coffaro and Bocci, 1997) and $\Psi$ is the saturation factor for nitrate $(1.5$ $\mathrm{m}^{3} \cdot \mathrm{mmolN}^{-1}$, Wroblewski, 1977).

2) for the two seagrass species ( $Z n$ and $Z m)$ :

$$
\lim (N)=\max \left(\lim (N)_{\text {wat }}, \lim \left(N_{4}^{+}\right)_{\text {sed }}\right)
$$

with,

$$
\lim (N)_{\text {wat }}=\lim \left(\mathrm{NH}_{4}^{+}\right)_{\text {wat }}+\lim \left(\mathrm{NO}_{3}^{-}\right)_{\text {wat }} \quad(7) ; \quad \lim \left(N \mathrm{H}_{4}^{+}\right)_{\text {sed }}=\frac{N H_{4 \text { sed }}^{+}}{N H_{4 \text { sed }}^{+}+K_{N}^{\prime}}
$$


where $\mathrm{NH}_{4 \text { sed }}^{+}$is the ammonium concentration in the interstitial waters (mmolN.m ${ }^{-3}$ ) and $\mathrm{K}_{\mathrm{N}}^{\prime}$ is the half-saturation coefficient for the sediment $\left(100 \mathrm{mmolN} \cdot \mathrm{m}^{-3}\right.$, Madden and Kemp, 1996).

\section{Macrophyte respiration:}

Macrophyte respiration is classically computed as a function of temperature (Eppley, 1972, Ménesguen and Salomon, 1987, Duarte and Ferreira, 1997). We also considered unpublished data by Auby and Levavasseur. Table 5 presents the calculated parameters.

Zimmerman et al. (1987) have shown that the frequent sediment anoxia allows respiration of seagrass roots and rhizomes only during daylight, photosynthesis providing sufficient oxygen to belowground organs. Consequently, in the model belowground respiration has been allowed only when GP is higher than the whole plant respiration (leaves plus rhizomes and roots). Belowground respiration will then be added to the leaf respiration calculated for the mesh in contact with sediment.

Furthermore, respiration rates of several algal species decrease when the concentration of dissolved oxygen is low (Dromgoole, 1978, Plus, 2001). A limitation function for the respiration has been therefore added to the model. The calculation of macrophyte respiration $\left(\operatorname{Resp}_{\mathrm{mac}}, \mathrm{gO}_{2} \cdot \mathrm{m}^{-3} \cdot \mathrm{d}^{-1}\right)$ is then:

$$
\operatorname{Resp} p_{\text {mac }}=\operatorname{Resp} \times \lim \left(\mathrm{O}_{2}\right) \times B
$$

with,

$$
\lim \left(\mathrm{O}_{2}\right)=\frac{\mathrm{O}_{2}}{\mathrm{O}_{2}+K_{\mathrm{O}_{2}}}
$$

where $\mathrm{O}_{2}$ is the concentration of dissolved oxygen in the water $\left(\mathrm{gO}_{2} \cdot \mathrm{m}^{-3}\right)$ and $\mathrm{K}_{\mathrm{O}_{2}}$ is the halfsaturation coefficient $\left(5 \mathrm{gO}_{2} \cdot \mathrm{m}^{-3}\right)$.

Macrophyte nitrogen uptake and mortality: 
The effect of macrophytes on nitrogen (uptake) and detritus (mortality) depends on production and respiration processes. Macrophyte production was transformed into nitrogen uptake according to equations (11) and (12). $\mathrm{GP}_{\text {mac }}$ was converted in fixed carbon using the photosynthetic quotient $\mathrm{PQ}=1.1$ (oxygen moles produced per mole of fixed carbon). The PQ was obtained as the average of the PQs of Ryther (1956), Buesa (1980) and Rosenberg et al. (1995). The quantity of fixed carbon is converted into nitrogen uptake using the mean C:N ratios of each species (Table 6). The total nitrogen uptake is then transformed in ammonium and nitrate uptake considering the concentrations of ammonium and nitrate in the water column:

$$
\begin{aligned}
U p t_{N H_{4}^{+}} & =0.027 \times \frac{G P_{\text {mac }}}{P Q \times C N} \times \frac{\lim \left(\mathrm{NH}_{4}^{+}\right)_{\text {wat }}}{\lim (N)_{\text {wat }}} \\
U p t_{\mathrm{NO}_{3}^{-}} & =0.027 \times \frac{G P_{\text {mac }}}{P Q \times C N} \times \frac{\lim \left(\mathrm{NO}_{3}^{-}\right)_{\text {wat }}}{\lim (N)_{\text {wat }}}
\end{aligned}
$$

where $\mathrm{Upt}_{\mathrm{NH}_{4}^{+}}$and $\mathrm{Upt}_{\mathrm{NO}_{3}^{-}}$are respectively the ammonium and nitrate uptakes, both expressed in mol N.m ${ }^{-3} \cdot \mathrm{d}^{-1}$ and $\mathrm{CN}$ is the annual mean carbon-nitrogen ratio as $\mathrm{gC} \cdot \mathrm{gN}^{-1}$.

Seagrasses, which are well adapted to poor nutrient environments have internal processes of nitrogen redistribution, from belowground parts to leaves and vice versa, and reclamation, from old to young tissues, (Zimmerman et al., 1987, Hemminga et al., 1991, Pedersen and Borum, 1992 and 1993). Pedersen and Borum (1993) have estimated that for Zostera marina the contribution of internal recycling accounts for nearly $30 \%$ of the annual nitrogen requirement. In this model, nitrogen uptake of the two seagrass species was therefore calculated as the $70 \%$ of the production; whilst it was considered as being $100 \%$ for all macroalgal species.

Macrophyte mortality (Mort ${ }_{\text {mac }}$, mol N.m ${ }^{-3} \cdot \mathrm{d}^{-1}$ ) was derived from respiration with the following equation: 


$$
\operatorname{Mort}_{\text {mac }}=0.027 \times \frac{R e s p_{\text {mac }}}{P Q \times C N}
$$

\subsection{Simulation characteristics}

Several simulations with (hereafter called $\mathrm{Mac}^{+}$) and without (hereafter called $\mathrm{Mac}^{-}$) macrophytes were performed with the 1996 data in order to assess the relationships between macrophyte communities and oxygen and nitrogen. Macrophyte mapping was carried out for the year 1998, the results being close to those describing the macrophyte populations in 1986 from Gerbal (1994) in terms of biomass, as well as in terms of species distribution. We thus assume in this study that macrophyte community is stable. Year 1996 has been chosen because (i) it shows large seasonal meteorological variations (a rainy winter contrasting with a dry summer) and (ii) a quite important database (water temperature, salinity, river inputs, nutrient concentrations, phytoplankton abundance, etc) was available in order to run and to validate the model. Meteorological data (Figure 4) were provided by the Fréjorgues Airport Météo-France station (irradiance, nebulosity, air temperature and humidity) and by the Sète semaphore (wind speed and direction). Unfortunately, nutrient and oxygen concentrations in waters coming from the Thau watershed or from the Mediterranean Sea were not available for year 1996, we thus assumed constant mean values throughout the year (table 7). Seasonal variations will thus only derive from varying river flow. When river flow measurements were not available (from July to December 1996), data were calculated using precipitation data following the same method as in Chapelle et al. (2000).

Two sets of one-month simulations, referring to the winter (January) and summer (June) conditions, were run and the results compared with experimental data. Furthermore, in order to estimate the annual macrophyte total production, the model has been run for a oneyear period. In order to test the sensitivity of the phytoplankton production to the macrophyte 
biomass, two further runs were performed with $+10 \%$ and $-10 \%$ modifications applied on the 'standard' macrophyte biomasses defined in Table 3.

\section{Results and discussion}

\subsection{Water column: winter simulation}

During January 1996 the water column was completely mixed due to high wind intensity. In the water column, both simulated temperature and salinity were homogeneous as shown in the T-S diagram Figure 5. Such profile pattern is usually described in the Thau lagoon excepted after long period of calm winds (Lazure, 1992). Simulated values are similar to mean winter salinity and temperature data: $8^{\circ} \mathrm{C}$ and salinity 30 (Deslous-Paoli and Vaquer, 1995, Gasc, 1997, Souchu et al., 2001).

In the centre of the lagoon, oxygen concentrations remain rather high, probably due to the phytoplankton production and water mixing by wind. In the macrophyte free water ( $\left.\mathrm{Mac}^{-}\right)$ oxygen saturation ranges between 70 and $105 \%$ whilst in the macrophyte zones (Mac + ) oxygen saturation is about $50 \%$ (Figure $6 \mathrm{~A}$ ). Macrophyte respiration and mineralization of organic matter are responsible for this higher oxygen consumption. However, simulated oxygen concentrations are in the range of data measured during the winter period: $50-135 \%$ of saturation according to Deslous-Paoli and Vaquer (1995) and Gasc (1997).

Nitrogen distribution is influenced by riverine inputs in the north and north-east parts of the lagoon and by the shellfish farming. This zonation of the lagoon is well described by the model outputs with ammonium concentrations ranging between 1.5 and 4 mmol.m ${ }^{-3}$ in the northern area, and less than $1.5 \mathrm{mmol} . \mathrm{m}^{-3}$ in the southern zone (Figure 6B). In the northern area the simulation $\mathrm{Mac}^{+}$shows that macrophytes account for a decrease of about $33 \%$ of the ammonium concentrations. In the southern parts of the lagoon, the rhizophytes seem to have a smaller influence on the water column nutrient concentrations. This pattern can be explained 
by the ecophysiology of seagrasses, which preferentially take up sedimentary nitrogen. In the Sète basin high ammonium concentrations are associated with high biomasses of nitrophilous opportunistic seaweeds such as Ulva rigida and Monostroma obscurum (Casellas et al., 1990, Picot et al., 1990). At the lagoon scale, simulated ammonium concentrations are in the range 2-4 mmol.m ${ }^{-3}$ reported for the winter period (Casellas et al., 1990, Picot et al., 1990, Amanieu et al, 1989, Gasc, 1997).

Differences between simulations $\mathrm{Mac}^{-}$and $\mathrm{Mac}^{+}$are very high when considering the detritus compartment (Figure 7A). The macrophyte impact is clearly perceptible at the two lagoon extremities, where the macrophyte biomasses are highest, i. e. in the west part of the lagoon, near the village of Marseillan, and in the northeast, near Sète. The centre of the lagoon exhibits the same detritus concentrations whether the macrophytes are included in the model or not. The $\mathrm{Mac}^{+}$simulated concentrations range between 0.1 and 4 mmolN.m ${ }^{-3}$, which are relatively low if compared with the experimental data of Souchu et al. (unpublished data, personal communication) who in January 1996 found values in the range from 3 to 20.3 mmolN.m ${ }^{-3}$. The method applied to calculate the mortality of macrophytes, using a constant $\mathrm{C}: \mathrm{N}$ ratio averaged on a yearly basis, could explain these low values. In the model we employ a constant $\mathrm{C}: \mathrm{N}$ ratio, however in the winter period the $\mathrm{C}: \mathrm{N}$ ratio could be higher since internal nitrogen pool is higher due to the nitrogen availability in the water column.

Simulated phytoplankton biomass is less affected by the introduction of macrophytes than the other variables. The biomasses (Figure 7B) range between 2 and 12 mmolN.m ${ }^{-3}$, with

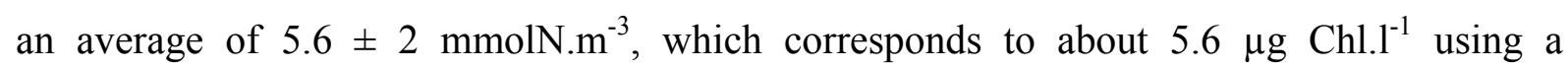
chlorophyll a/ $\mathrm{N}$ ratio of $1 \mathrm{~g} \cdot \mathrm{mol}^{-1}$ (Eppley et al., 1971). These values are in accordance with data reported in the literature for the Thau lagoon in the winter period: $0.2-4 \mu \mathrm{g}$ Chl. . $^{-1}$

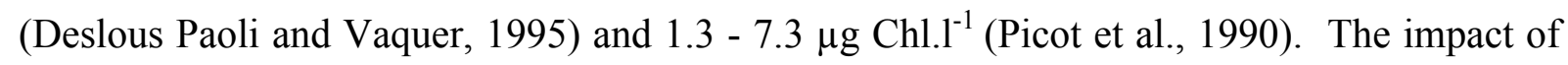


the bivalves' filtration on the phytoplankton can be seen, reducing the biomass in the farming zone to $2 \mu \mathrm{g} \mathrm{Chl.1}{ }^{-1}$.

\subsection{Summer simulations}

As in winter 1996, the winds that blew in June were sufficient to prevent the formation of stratification in the lagoon (Figure 5).

Simulated oxygen concentrations are lower than in winter due to faster mineralization processes and lower solubility in warm waters. The introduction of macrophyte populations changes significantly the dissolved oxygen distribution in the Thau lagoon (Figure 8A). The organic dead material accumulation coupled with higher oxygen consumption due to high summer temperature lead to the appearance of three under-saturated areas: the first in the western extremity of the lagoon including shellfish zone C, where highest macrophyte biomasses are located, and the second and third areas are the oriental part of the lagoon, the shellfish zone A and the Sète basin. Oxygen concentrations fall to about $20 \%$ of the saturation $\left(1.5 \mathrm{mg} . \mathrm{l}^{-1}\right)$ in the West and to $7 \%$ of the saturation $\left(0.5 \mathrm{mg} . \mathrm{l}^{-1}\right)$ in the East. Influence of marine waters can be observed close to the Sète canals, where concentrations remain at higher levels $\left(7 \mathrm{mg} \cdot \mathrm{l}^{-1}\right)$. Simulations show that oxygen concentrations not only depend on in situ biogeochemical processes, but also on the currents. Such a hydrodynamical influence can be observed for example in the East where some oxygen poor water is transported towards the shellfish farming zone A. The centre and the south of the lagoon exhibit higher concentrations, ranging between 5.5 and $7.5 \mathrm{mg} \cdot \mathrm{l}^{-1}$.

Contrary to the winter period, the insertion of macrophytes in the model does not lead to a decrease in ammonium concentrations, but increases concentrations in most sectors (Figure 8B). The macrophyte uptake then, does not match the remineralization process, particularly active at higher temperatures. On the basis of the simulated distribution of ammonium concentrations, macrophytes could be considered as a positive factor for nutrients 
in summer, enhancing by their presence, the detritus pool that lead to a higher remineralization. In the West, near Marseillan, simulation $\mathrm{Mac}^{+}$exhibits concentrations up to 6.2 mmol. $\mathrm{m}^{-3}$, nearly 5 times the concentrations simulated without macrophytes. In the same way, ammonium concentrations in the shellfish farming zone A are higher in simulation $\mathrm{Mac}^{+}$ with concentrations ranging between 1.4 and $6.5 \mathrm{mmol} . \mathrm{m}^{-3}$, and, to a smaller extent, the same pattern occurs in the extreme East of the lagoon. The simulated concentrations are close to the experimental data ranging $0.1-25$ mmol.m ${ }^{-3}$, Picot et al. (1990), Gasc (1997) and Souchu et al. (1998).

The simulated detritus distribution is directly correlated to the macrophyte distribution, with maximum concentrations $\left(20-25 \mathrm{mmol} \mathrm{N} . \mathrm{m}^{-3}\right)$ in the western part of the lagoon (Figure 9A). In the centre of the lagoon, the model simulates the lowest concentrations (around $2 \mathrm{mmol} \mathrm{N} . \mathrm{m}^{-3}$ ) while mean concentrations are $10.9 \pm 4.3 \mathrm{mmol} \mathrm{N} . \mathrm{m}^{-3}$ in the West and $5.5 \pm 2.9 \mathrm{mmol} \mathrm{N} \cdot \mathrm{m}^{-3}$ in the East. These concentrations are in agreement with experimental measurements between 0.1-14 mmol N.m (Gasc, 1997, Souchu et al., 1998).

The north border of the lagoon is the sector where highest phytoplankton concentrations are found, contrasting with the south, along the "Lido", where more oligotrophic conditions are simulated (Figure 9B). If maxima remain below those calculated in winter, $12 \mathrm{mmol} \mathrm{N} . \mathrm{m}^{-3}$ in January and $7.9 \mathrm{mmol} \mathrm{N} . \mathrm{m}^{-3}$ in June, the mean concentration is

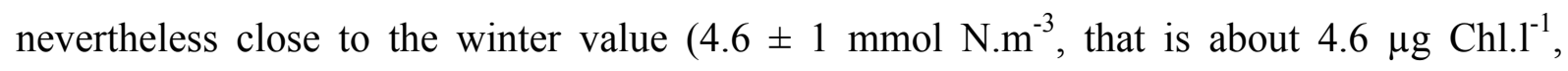
simulation $\mathrm{Mac}^{+}$) implying a more homogeneous distribution. General patterns of phytoplankton distribution are not modified by the introduction of macrophytes. Following our simulations, competition between phytoplankton and macrophyte seems thus to be unlikely. Inversely, the impact of shellfish filtration is important, indeed, simulated concentrations inside the shellfish cultivation zones are 15 to $20 \%$ lower than those immediately outside. All simulated values are similar to those reported in the literature for the 
same season (0.1 - 15 mmol N.m ${ }^{-3}$ ), Pichot et al. (1994), Gasc (1997) and Souchu et al. (1998).

\subsection{Sediment compartment}

Simulation results, as well as some data from the literature are presented in table 8 .

The ammonium concentration simulated by the model is roughly in accordance with field data. The introduction of macrophytes in the model tends to slightly decrease the ammonium concentration throughout the year. This impact is obviously more important in the areas covered by seagrass meadows, where nutrient uptake can be also undertaken by rhizomes and roots. Minima are therefore calculated near the Lido in the south of the lagoon, while maxima are simulated in the shellfish cultivation zone A and near in the East near Sète.

Concerning the detritus, model $\mathrm{Mac}^{+}$simulates the lagoon maximum concentrations in the shellfish farming zone A, during summer. The introduction of macrophytes in the model slightly increases detritus concentrations in the sediment, mostly where seagrasses are located, because of the death of belowground organs (data not shown). Nevertheless, values simulated by the model remain below the experimental data from Deslous-Paoli et al. (1998) or Laugier et al. (1999). This under estimation may be due to the fact that the model only considers the fraction of organic matter available for mineralization processes and not the refractory organic matter, while measurements include both forms.

Oxygen concentrations in interstitial waters do not show any differences whether the macrophytes are present in the model or not. Simulations show a complete absence of oxygen in sediment whatever the period. This pattern is not surprising if we consider that measurements have shown that oxygen completely disappears below a few millimetres in Thau lagoon sediments (Chapelle, 1995, Mazouni, 1995, Deslous-Paoli et al., 1998).

\subsection{Assessment of the annual macrophyte production at the whole lagoon scale}


The simulated macrophyte annual gross production is 27300 tons of carbon, which corresponds to 1680 tons of nitrogen (Table 9). This value is 2.5 fold less than the simulated phytoplankton annual gross production in terms of nitrogen (about 4300 tons $\mathrm{N}^{-y^{-1}}$ ). The latter value is close to that estimated by Chapelle et al. (2000) for the phytoplankton, namely $3570 \mathrm{t} \mathrm{N} \cdot \mathrm{y}^{-1}$. Such a difference between macrophyte and phytoplankton production can be explained by the relative important depth of the Thau lagoon, which implies that about one third of the lagoon bottom is absolutely devoid of macrophytes (Gerbal, 1994). Furthermore, macrophytes have little influence on the annual phytoplankton production, with changes of $2.4 \%$ and $+0.2 \%$ when applying respectively $-10 \%$ and $+10 \%$ to the macrophyte biomass.

When compared to other temperate lagoons (Table 10), the results obtained stress the high productivity of the Thau lagoon. Indeed, the model calculates phytoplankton and macrophyte productions higher than in other lagoons such as Lake Grevelingen (North Sea), the Bassin d'Arcachon (Atlantic), or the central part of the Venice lagoon (Adriatic). Arcachon and Venice can be opposed to Grevelingen and Thau regarding both nitrogen inputs and the water residence time and those characteristics have probably a direct impact on the lagoons biogeochemistry and on the balance between new and regenerated productions. Since the nitrogen inputs in the Thau lagoon are small when compared to these lagoons, and the water residence time is long, this high productivity is probably supported by an important level of internal nutrient regeneration, confirming the results from Chapelle et al. (2000). However, these preliminary results have to be considered with care as the model is not fully validated and production for all compartments (phytoplankton, microphytobenthos, and macrophytes) has not been estimated for all lagoons.

\section{Conclusion}


Macrophytes have a considerable impact in the Thau lagoon ecosystem functioning. From simulated results, the main effects are on the biogeochemical cycles (oxygen, ammonium, nitrates and detritus) rather than on trophic relationships, because of the lower impacts on the phytoplankton compartment.

The inclusion of macrophyte in the model leads to a strong small-scale spatial structuring. This spatial pattern forms an east-west gradient particularly obvious for oxygen and organic detrital nitrogen variables. Furthermore, this gradient, already noted by Gerbal (1994) and Gerbal and Verlaque (1995), is combined with another gradient (north-south) caused by the watershed inputs and the shellfish cultivation zones (Deslous-Paoli et al., 1998): higher nutrient concentrations, fine sediments with high organic load in the north and more oligotrophic conditions with sandy sediment in the south.

Both extremities (East-West) of the lagoon are characterised by high quantities of organic material which during summer can lead to oxygen depletion. Thus, these sectors can be considered as areas where risks of anoxic crisis are higher. Tournier et al. (1990), have already stressed that the shellfish farming zones show higher anoxia risks, particularly zone A. We demonstrated that also zone $\mathrm{C}$ can be potentially at risk. Nonetheless, the oriental part of the lagoon near the town of Sète has never been considered an area having an important risk of anoxia (Deslous-Paoli, personal communication). An underestimation of the consequence of marine oxygenated water entering into the lagoon through Sète canals, could explain such a discrepancy.

During rainy events (principally in autumn and winter), nutrient inputs from the watershed support the uptake of macrophytes and phytoplankton, while during dry periods mineralization processes become dominant, thus allowing a primary production based mostly on nutrient regeneration. Macrophyte represent a quite important nitrogen stock (about 170 tons according to Gerbal, 1994), whose fluctuations have lower frequency and amplitude than 
phytoplankton fluctuations. Part of this nitrogen stock can be released in the water column through macrophyte mortality and decomposition and can feed phytoplankton growth. The model replicates these mechanisms during summer period.

This three dimensional model has contributed, with macrophytes as forcing variables, to a preliminary understanding of the impact of macrophytes on the biogeochemical cycles of the Thau lagoon. A first estimation of the total annual macrophyte productivity at the whole lagoon scale has been proposed and allowed comparisons with other primary producers and other temperate lagoons. These comparisons have underlined the very important productivity of the Thau lagoon. We have nonetheless to keep in mind that this model represents a first step in modelling the extraordinary complexity of macrophyte communities in the Thau ecosystem.

\section{Acknowledgements}

This research was supported by the French National Program on Coastal Environment (PNEC "Chantier Lagunes Méditerranéennes"). We would like to thank Philippe Gros who kindly advised us on statistics. We would also like to thank the referees for their very useful comments. 


\section{References}

Amanieu M., Legendre P., Trousselier P., Frisoni G. F., 1989. Le programme ecoThau: théorie, écologie et base de modélisation. Oceanologica acta 12, 189-199.

Anonymous, 1997. Suivi des apports du bassin versant de l'étang de Thau et des échanges avec la mer par les canaux de Sète. Contrat pour l'étang de Thau, volet a: études et recherches. Montpellier University 1 et 2, UMR 5569 et 5556.

Auby I., 1991. Contribution à l'étude des herbiers de Zostera noltii dans le bassin d'Arcachon: dynamique, production et dégradation, macrofaune associée. Ph.D. Thesis University of Bordeaux 1, unpublished.

Auby I., Bachelet G., Labourg P. J., 1993. Biomass and species composition of macrophytes in Arcachon Bay and Prévost lagoon, with a compilation of data on primary production in Arcachon Bay. C.1.e.an. (Coastal lagoon eutrophication and anaerobic processes) Progress report, $65-72$.

Auby I., Manaud F., Maurer D., Trut G., 1994. Etude de la prolifération des algues vertes dans le Bassin d'Arcachon. Rapport Ifremer - Cémagref - SSA - SABARC.

Bacher C., Millet B. Vaquer A., 1997. Modélisation de l'impact des mollusques cultivés sur la biomasse phytoplanctonique de l'étang de Thau (France). C. R. Acad. Sci. Ser. 3 sci. Vie/life SSC. 320, 73-81.

Buesa R. J., 1980. Photosynthetic quotient of marine plant. Photosynthetica 14 (3), 337-342.

Carreira J., Clavero V., Galvez J. A., Guevara J., Hernandez I., Lucena J., Niell F. X., Peralta G., Perez-llorens J. L., Rodriguez R., Vergara J. J., 1994. Eutrophication processes in estuaries situated at the end of small catchment areas. In: Proceeding of the first EUMAC workshop held in Venice, 25-27 November 1994. 
Casellas C., Pena G., Picot B., Illes S., Bontoux J., 1990. Structure spatiale des sels nutritifs au sein d'un écosystème lagunaire: l'étang de Thau. Water research 24 (12), 1479-1489.

Chapelle A., 1995. A preliminary model of nutrient cycling in sediments of a mediterranean lagoon. Ecological modelling 80, 131-147.

Chapelle A., Lazure P., Souchu P., 2001. Modélisation des crises anoxiques (malaïgues) dans la lagune de Thau (France). Oceanologica acta 24, 87-97.

Chapelle A., Menesguen A., Deslous-Paoli J. M., Souchu P., Mazouni N., Vaquer A., Millet B., 2000. Modelling nitrogen, primary production and oxygen in a mediterranean lagoon. Impact of oysters farming and inputs from the watershed. Ecological modelling 127 (2-3), 161-181.

Coffaro G., Bocci M., 1997. Resources competition between Ulva rigida and Zostera marina: a quantitative approach applied to the lagoon of Venice. Ecological Modelling 102, 81-95.

Collos Y., Vaquer A., Bibent B., 1997. Variability in nitrate uptake kinetics of phytoplankton communities in a Mediterranean coastal lagoon. Oceanographic Literature Review 44, p. 802.

Conover R. J., 1966. Assimilation of organic matter by zooplankton. Limn. Oceanogr. 11, $338-345$.

Deslous-Paoli J.-M. (ed.), 1995. Programme Oxythau. Le bassin de Thau: relation milieu ressources dans les secteurs conchylicoles. Importance des mécanismes d'échanges verticaux. 1991-1995.

Deslous-Paoli J.-M., Souchu P., Mazouni N., Juge C., Dagault F., 1998. Relation milieuressources: impact de la conchyliculture sur un environnement lagunaire Méditerranéen (Thau). Oceanologica acta 21 (6), 831-843.

Deslous-Paoli J.-M., Vaquer A., 1995. Interactions filtreurs-microorganismes: apport a 
l'analyse des systèmes et a la gestion des milieux côtiers. In: Compte-rendu d'activité de l'URM 5 pour 1992-1995, University of Montpellier, unpublished.

Dromgoole F. I., 1978. The effect of oxygen on dark respiration and apparent photosynthesis of marine macro-algae. Aquat. Bot. 4 (3), 281-297.

Duarte P., Ferreira J. G., 1997. A model for the simulation of macroalgal population dynamics and productivity. Ecological modelling 98 (2-3), 199-214.

Eppley R. W., 1972. Temperature and phytoplankton growth in the sea. Fish. Bull. 70, 10631085.

Eppley R. W., Rogers J. B., Mc carthy J. J., Sournia A., 1971. Light/dark periodicity in nitrogen assimilation of the marine phytoplankters Skeletonema costatum and Coccolithus huxley in n-limitant chemostat culture. J. Phycol. 7, 150-154.

Gasc A., 1997. Etude de la production primaire régénérée dans un écosystème conchylicole: le bassin de Thau. Ph.D. thesis, University of Montpellier 2, unpublished.

Gerbal M., 1994. Analyse spatio-temporelle des peuplements phytobenthiques de substrat meuble de l'étang de Thau (herault, France). Ph.D. thesis, University of Aix-Marseille 2, unpublished.

Gerbal M., Verlaque M., 1995. Macrophytobenthos de substrat meuble de l'étang de Thau (France, Méditerranée) et facteurs environnementaux associés. Oceanologica acta 18 (5), 557-571.

Grias P., 1992. Les communautés de macrophytes submergées des marais temporaires oligohalins de camargue. Etude expérimentale des causes de la distribution des espèces. Ph.D. thesis, University of Rennes, unpublished.

Hemminga M. A., Harrison P. G. Van lent F., 1991. The balance of nutrient losses and gains 
in seagrass meadows. Mar. Ecol. Prog. Ser. 71, 85-96.

Henley W. J., Levavasseur G., Franklin L. A., Osmond C. B., Ramus J., 1991. Photoacclimatation and photoinhibition in Ulva rotundata as influenced by nitrogen availability. Planta 184, 235-243.

Iizumi H., Hattori A., 1982. Growth and organic production of eelgrass (Zostera marina L.) In temperate waters of the pacific coast of japan. III. The kinetics of nitrogen uptake. Aquat. Bot. 12, 245-256.

Ivlev V. S., 1955. Experimental ecology of the feeding fishes. In: Yale University Press, New Haven.

Jassby A. D., Platt T., 1976. Mathematical formulation of the relationship between photosynthesis and light for phytoplankton. Limnology and oceanography 21 (4), 540-547.

Knoppers B., 1994. Aquatic primary production in coastal lagoons. In: Kjerfve, B. (ed.), Coastal lagoon processes, pp. 243-286.

Laugier T., Rigollet V., De Casabianca M. L., 1999. Seasonal dynamics in mixed eelgrass beds, Zostera marina L. and Z. noltii Hornem., in a Mediterranean coastal lagoon (Thau lagoon, France). Aquat. Bot. 63 (1), 51-69.

Lazure P., 1992. Etude de la dynamique de l'étang de Thau par modèle numérique tridimensionnel. Vie milieu 42 (2), 137-145.

Madden C., Kemp J., 1996. Ecosystem model of an estuarine submersed plant community: calibration and simulation of eutrophication responses. Estuaries 19, 457-474.

Mazouni N., 1995. Influence des élevages ostréicoles sur le fonctionnement d'un ecosystème lagunaire Méditerranéen. Etude in situ de l'influence des filtreurs (coquillages et epibiontes) 
sur les flux de matières particulaires et dissoutes. Ph.D. thesis, University of Marseille 2, unpublished.

Ménesguen A., 1992. Modelling coastal eutrophication: the case of french Ulva mass blooms. Science of the total environment supplement 1992, 979-992.

Ménesguen A., Piriou J.-Y., 1995. Nitrogen loadings and macroalgal (Ulva sp.) Mass accumulation in Brittany (France). Ophelia 42, 227-237.

Ménesguen A., Salomon J., 1987. Eutrophication modelling as a tool for fighting against Ulva coastal mass blooms. In: Schrefler, B. A. (ed.), Computer modelling in ocean engineering, pp. 443-450.

Mesnage V., 1994. Contribution à l'étude de la mobilité des formes de phosphates à l'interface eau-sédiment dans les écosystèmes lagunaires. Ph.D. thesis, University of Montpellier 1, unpublished.

Newel R. C., 1982. The energetics of detritus utilization in coastal lagoons and nearshore waters. In: Actes du symposium International sur les lagunes Côtières, SCOR/IABO/UNESCO, Bordeaux 8-14 sept. 1981, Oceanologica Acta vol. sp. 3, 347-355.

Nienhuis P. H., 1992. Ecology of coastal lagoons in the Netherlands (Veerse Meer and Grevelingen). Vie Milieu 42, 59-72.

Nienhuis P. H., De bree H. H., 1980. Production and growth dynamics of eelgrass (Z. Marina) in brackish Lake Grevelingen (The Netherlands). Neth. J. Sea res. 14, 102-118.

Pedersen M. F., Borum J., 1992. Nitrogen dynamics of eelgrass Zostera marina during a late summer period of high growth and low nutrient availability. Marine Ecology Progress Series $80,65-73$. 
Pedersen M. F., Borum J., 1993. An annual nitrogen budget for a seagrass Zostera marina population. Mar. Ecol. Prog. Ser. 101, 169-177.

Pichot P., Ximenes M. C. Deslous-Paoli J. M. Juge C., 1994. Bilan de l'azote et du phosphore dans le système lagune-bassin versant de Thau. In: Contrat de plan Etat-Région LanguedocRoussillon, R. Int. Ifremer del/94.11/sète, unpublished.

Picot B., Péna G. Casellas C. Bondon D. Bontoux J., 1990. Interpretation of the seasonal variations of nutrients in a mediterranean: étang de Thau. Hydrobiologia 207, 105-114.

Plus M., 2001. Etude et modélisation des populations de macrophytes dans la lagune de Thau (Hérault, France). Ph.D. thesis, University of Paris 6, unpublished.

Redfield A. C., Ketchum B. H., Richards F. A., 1963. The influence of organisms on composition of seawater. In: Hill, M. N. (ed), The sea, vol. II, pp 26-77.

Rigollet V., Laugier T., De Casabianca M. L., Sfriso A., Marcomini A., 1998. Seasonal biomass and nutrient dynamics of Zostera marina L. in two Mediterranean lagoons: Thau (France) and Venice (Italy). Bot. Mar. 41, 167-179.

Rismondo A., Curiel D., Marzocchi M., Micheli C., 1995. Autoecology and production of Zostera marina in Venice lagoon. Rapp. Comm. Int. Mer médit. 34, 42.

Rosenberg G., Littler D. S., Littler M. M., Oliveira E. C., 1995. Primary production and photosynthesic quotients of seaweeds from Sao Paulo state, Brazil. Bot. Mar. 38, 369-377.

Ryther J. H., 1956. The measurement of primary production. Limnol. Oceanogr. 1, 72-84.

Sand-Jensen K., 1975. Biomass, net production and growth dynamics in an eelgrass (Zostera marina L.) population in Vellerup Vig., Denmark. OPHELIA 14, 185-201.

Sfriso A., Marcomini A., 1996. Italy - The lagoon of Venice. In: W. Schramm and P. Nienhuis (eds.), Ecological Studies 123, pp. 339-368. 
Sfriso A., Pavoni B., Marcomini A., 1989. Macroalgae and phytoplankton standing crops in the central Venice lagoon: primary production and nutrient balance. Sci. Total environ. 80 (23), 139-159.

Short F. T., 1980. A simulation model of the seagrass production system. In: Phillips, R.C. and Mc Roy C.P. (eds.), Handbook of seagrass biology: an ecosystem perspective, 277-295.

Short F. T., 1987. Effects of sediment nutrient on seagrasses: literature review and mesocosm experiment. Aquat. Bot. 27, 41-57.

Short F. T., Mc Roy C. P., 1984. Nitrogen uptake by leaves and roots of the seagrass Zostera marina L.. Bot. Mar. 27, 547-555.

Simon C., Ar Gall E., Levavasseur G., Deslandes E., 1999. Effects of short term variations of salinity and temperature on the photosynthetic response of the red alga Grateloupia doryphora from Brittany (France). Bot. Mar. 42, 437-440.

Solidoro C., Pecenik G., Pastres R., Franco D., Dejak C., 1997. Modelling macroalgae (Ulva rigida) in the Venice lagoon: model structure identification and first parameters estimation. Ecol. Model. 94, 191-206.

Souchu P., Gasc A., Cahet G., Vaquer A., Collos Y., Deslous-Paoli J. M., 1997. Biogeochemical composition of mediterranean waters outside Thau lagoon. Estuar. Coast. Shelf. Sci. 44 (3), 275-284.

Souchu P., Gasc A., Collos Y., Vaquer A., Tournier H., Bibent B., Deslous-Paoli J.-M., 1998. Biogeochemical aspects of bottom anoxia in a mediterranean lagoon (Thau, France). Mar. Ecol. Prog. Ser.164, 135-146.

Souchu P., Vaquer A., Collos Y., Landrein S., Deslous-Paoli J.-M., Bibent B., 2001. Influence of shellfish farming activities on the biogeochemical composition of the water column in Thau lagoon. Mar. Ecol. Prog. Ser. 218, 141-152. 
Splus, 1997. S-plus 4, In: Guide to statistics. Mathsoft, Inc (ed.).

Thursby G. B., Harlin M. M., 1982. Leaf-root interaction in the uptake of ammonia by Zostera marina L.. Marine biology 72, 109-112.

Touchette B. W., Burkholder J. M., 2000. Review of nitrogen and phosphorus metabolism in seagrasses. J. Exp. Mar. Biol. Ecol. 250, 133-167.

Tournier H., Audabram D. Landrein S. Deslous-Paoli J. M., 1990. L'oxygène en été dans l'étang de Thau. Contribution à l'étude du risque de "malaïgue". In: Rapport interne de la direction des ressources océaniques, laboratoire environnement méditerranéen, Ifremer Sète, unpublished.

Vegter F., De vissher P. R. M., 1984. Phytoplankton production in brackish Lake Grevelingen (SW Netherlands) during 1976-1981. Neth. J. Sea res. 18 (3-4), 246-259.

Verlaque M., 2001. Checklist of the macroalgae of Thau lagoon (Hérault, France), a hot spot of marine species introduction in Europe. Oceanologica acta 24, 29-49.

Viaroli P., Bartoli M., Bondavalli C., Christian R. R., Giordani G., Naldi M., 1996. Macrophyte communities and their impact on benthic fluxes of oxygen, sulphide and nutrients in shallow eutrophic environments. Hydrobiologia 329, 105-119.

Wen Y. H., Peters R. H., 1994. Empirical models of phosphorus and nitrogen excretion rates by zooplankton. Limnol. Oceanogr. 39, 1669-1680.

Wroblewski J. S., 1977. A model of phytoplankton bloom formation during variable Oregon upwelling. J. Mar. Res. 35, 357-394.

Zimmerman R. C., Smith R. D., Alberte R. S., 1987. Is growth of eelgrass nitrogen limited ? A numerical simulation of the effect of light and nitrogen on the growth dynamics of Zostera marina. Mar. Ecol. Prog. Ser. 41, 167-176. 
Table 1. List of equations and parameters linked to phytoplankton ( $\varphi$ pk) and zooplankton (zpk) processes. References: 1. Eppley (1972); 2, Chapelle et al. (2000); 3, Collos et al. (1997); 4, Wroblewski (1977); 5, Ivlev (1955); 6, Conover (1966); 7, Wen and Peters (1994).

\section{Equations}

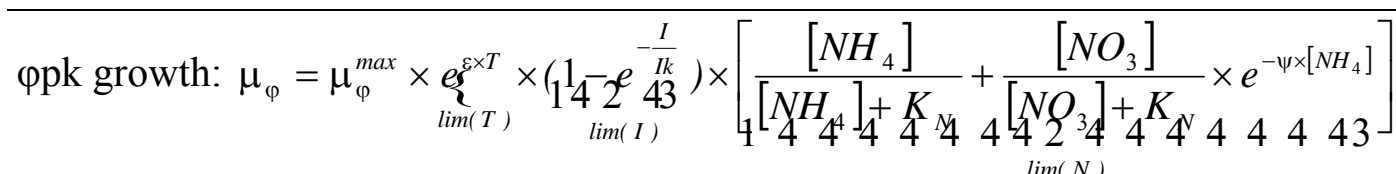

ppk nitrogen uptake: $U_{N H 4}=\mu_{\varphi} \times \frac{\left[N H_{4}\right]}{\left[N H_{4}\right]+K_{N}} / \lim (N) ; U_{N O 3}=\mu_{\varphi} \times \frac{\left[N O_{3}\right]}{\left[N O_{3}\right]+K_{N}} / \lim (N)$

ppk mortality: $m_{\varphi}=m_{\varphi}^{0^{\circ} \mathrm{C}} \times \lim (T) ; \varphi p k$ respiration: $r_{\varphi}=r_{\varphi}^{0^{\circ} \mathrm{C}} \times \lim (T)$

zpk grazing: $g=g^{0^{\circ} C} \times \lim (T) \times\left(1-e^{-R \times \operatorname{Max}\left[0,\left(B_{\varphi}-S\right)\right.}\right) \quad$ with $\mathrm{B}_{\varphi}=\varphi p k$ biomass

zpk growth: $\mu_{z}=A \times g$; zpk faeces: $f=(1-A) \times g ;$ zpk mortality: $m_{z}=m_{z}^{0^{\circ} \mathrm{C}} \times \lim (T)$

zpk excretion: $E_{z}=\operatorname{Max}\left[g \times E_{1}, E_{2} \times \lim (T)\right] ; \quad$ zpk respiration: $r_{z}=r_{z}^{0^{\circ} \mathrm{C}} \times \lim (T)$

\begin{tabular}{lll}
\hline Phytoplankton parameters & Value & References \\
\hline$\mu_{\varphi}^{\text {max }}$, maximum growth rate at $0^{\circ} \mathrm{C}$ & $0.5 \mathrm{~d}^{-1}$ & calibrated \\
$\varepsilon$, temperature $\left(\mathrm{T}\right.$ in $\left.{ }^{\circ} \mathrm{C}\right)$ coefficient & $0.07^{\circ} \mathrm{C}^{-1}$ & 1 \\
$\mathrm{Ik}$, saturation light $\left(\mathrm{I}\right.$ in $\left.\mathrm{W} \cdot \mathrm{m}^{-2}\right)$ intensity & $30 \mathrm{~W} \cdot \mathrm{m}^{-2}$ & calibrated \\
$\mathrm{K}_{\mathrm{N}}, 1 / 2$ saturation constant for N limitation & $2 \mathrm{mmol} \cdot \mathrm{m}^{-3}$ & 3 \\
$\psi$, Wroblewski inhibition factor & $1.5 \mathrm{~m}^{3} \cdot \mathrm{mmol}^{-1}$ & 4 \\
$m_{\varphi}^{0^{\circ} \mathrm{C}}$, mortality rate at $0^{\circ} \mathrm{C}$ & $0.005 \mathrm{~d}^{-1}$ & 2 \\
$r_{\varphi}^{0^{\circ} \mathrm{C}}$, respiration rate at $0^{\circ} \mathrm{C}$ & $0.05 \mathrm{~d}^{-1}$ & 2 \\
\hline $\mathrm{Zooplankton}$ parameters & $\mathrm{Value}^{-1}$ & References \\
\hline$g^{0^{\circ} \mathrm{C}}$, grazing rate at $0^{\circ} \mathrm{C}$ & $0.4 \mathrm{~d}^{-1}$ & calibrated \\
$\mathrm{R}$, Ivlev constant & $0.05 \mathrm{~m}^{3} \cdot \mathrm{mmol}^{-1}$ & 5 \\
$\mathrm{~S}$, threshold for phytoplankton ingestion & $0.05 \mathrm{mmol}^{-3}$ & calibrated \\
$\mathrm{A}, \%$ of assimilation & 0.6 & 6 \\
$\mathrm{E}_{1}, \%$ of excretion & 0.15 & 2 \\
$\mathrm{E}_{2}$, minimal excretion rate at $0^{\circ} \mathrm{C}$ & $0.025 \mathrm{~d}^{-1}$ & 7 \\
$m_{z}^{0^{\circ} \mathrm{C}}$, mortality rate at $0^{\circ} \mathrm{C}$ & $0.01 \mathrm{~d}^{-1}$ & 2 \\
$r_{z}^{0^{\circ} \mathrm{C}}$, respiration rate at $0^{\circ} \mathrm{C}$ & $0.084 \mathrm{~d}^{-1}$ & 2 \\
\hline
\end{tabular}


Table 2. Selected species for the model and labels used in the text, tables and figures.

\begin{tabular}{lc}
\hline Species & Labels \\
\hline Halopitys incurvus & $\mathrm{Hi}$ \\
Zostera marina & $\mathrm{Zm}$ \\
Zostera noltii & $\mathrm{Zn}$ \\
Gracilaria compressa & $\mathrm{Gc}$ \\
Chaetomorpha linum & $\mathrm{Cl}$ \\
Gracilaria dura & $\mathrm{Gd}$ \\
Rytiphloea tinctoria & $\mathrm{Rt}$ \\
Gracilariopsis longissima & $\mathrm{Gl}$ \\
Ulva rigida & $\mathrm{Ur}$ \\
Monostroma obscurum & $\mathrm{Mo}$ \\
\hline
\end{tabular}


Table 3. Biomass $\left(\mathrm{gDW} \cdot \mathrm{m}^{-2}\right)$ of the dominant species in each considered zone. The area of each zone is given in brackets. The thickness of the macrophyte bed $(\mathrm{H})$, which is considered in the model, is also reported.

\begin{tabular}{|c|c|c|c|c|c|c|c|c|}
\hline & $\mathrm{H}(\mathrm{cm})$ & $\begin{array}{l}\text { Zone } 1 \\
\left(10 \mathrm{~km}^{2}\right)\end{array}$ & $\begin{array}{l}\text { Zone } 2 \\
\left(3 \mathrm{~km}^{2}\right)\end{array}$ & $\begin{array}{l}\text { Zone } 3 \\
\left(6.6 \mathrm{~km}^{2}\right)\end{array}$ & $\begin{array}{l}\text { Zone } 4 \\
\left(6.7 \mathrm{~km}^{2}\right)\end{array}$ & $\begin{array}{l}\text { Zone } 5 \\
\left(11 \mathrm{~km}^{2}\right)\end{array}$ & $\begin{array}{l}\text { Zone } 6 \\
\left(6 \mathrm{~km}^{2}\right)\end{array}$ & $\begin{array}{l}\text { Zone } 7 \\
\left(26.5 \mathrm{~km}^{2}\right)\end{array}$ \\
\hline $\mathrm{Hi}$ & 50 & 382 & 0 & 0 & 0 & 0 & 0 & 0 \\
\hline $\mathrm{Zm}$ & 100 & 42 & 0 & 119 & 44 & 0 & 0 & 0 \\
\hline$Z n$ & 35 & 0 & 341 & 0 & 180 & 0 & 0 & 0 \\
\hline Gc & 30 & 0 & 0 & 0 & 0 & 55 & 154 & 0 \\
\hline $\mathrm{Cl}$ & 30 & 0 & 0 & 0 & 0 & 97 & 0 & 0 \\
\hline$G d$ & 20 & 0 & 0 & 0 & 0 & 38 & 0 & 0 \\
\hline$R t$ & 20 & 38 & 0 & 0 & 0 & 0 & 0 & 0 \\
\hline$G l$ & 20 & 0 & 0 & 0 & 0 & 12 & 55 & 0 \\
\hline$U r$ & 20 & 0 & 0 & 0 & 0 & 0 & 46 & 0 \\
\hline Mo & 20 & 0 & 0 & 0 & 0 & 0 & 59 & 0 \\
\hline $\begin{array}{l}\text { Tota } \\
\text { (ton }\end{array}$ & $\begin{array}{l}\text { l biomass } \\
\text { DW) }\end{array}$ & 4620 & 1023 & 785 & 1505 & 2222 & 1884 & 0 \\
\hline
\end{tabular}


Table 4. Mean annual saturation light coefficient $\left(\overline{\mathrm{I}_{\mathrm{k}}}, \mu \mathrm{mol}\right.$ photons. $\left.\mathrm{m}^{-2} \cdot \mathrm{s}^{-1}\right)$ and relationships between temperature $\left(\mathrm{T}\right.$, in $\left.{ }^{\circ} \mathrm{C}\right)$ and maximum production rates $\left(\mathrm{P}_{\max }, \mathrm{gO}_{2} \cdot \mathrm{gDW}^{-1} \cdot \mathrm{d}^{-1}\right)$ for the ten selected species. A linear $\left(P_{\max }=a T+b\right)$ and an exponential $\left(P_{\max }=a \times e^{b T}\right)$ regressions were tested for each species. The $\mathrm{a}$ and $\mathrm{b}$ values are reported for the equation showing the best regression coefficient $\left(\mathrm{R}^{2}\right)$. The mean $\overline{\mathrm{P}_{\max }}$ value is reported and used in the model when the regression is not significant.

\begin{tabular}{|c|c|c|c|c|c|c|c|}
\hline & \multirow[t]{2}{*}{$\overline{\mathrm{I}_{\mathrm{k}}}$} & \multicolumn{6}{|c|}{$\mathrm{P}_{\max }$} \\
\hline & & $\mathrm{R}^{2}$ & $\mathrm{n}$ & type & $\mathrm{a}$ & $\mathrm{b}$ & $\overline{\mathrm{P}_{\max }}$ \\
\hline $\mathrm{Hi}$ & 153 & 0.99 & 9 & linear** & 0.011 & -0.037 & \\
\hline $\mathrm{Zm}$ & 228 & 0.99 & 12 & linear* & 0.036 & -0.193 & \\
\hline$Z n$ & 241 & 0.88 & 12 & linear* & 0.027 & -0.054 & \\
\hline Gc & 227 & ns & 12 & ns & & & 0.143 \\
\hline $\mathrm{Cl}$ & 144 & ns & 12 & ns & & & 0.257 \\
\hline$G d$ & 126 & 0.96 & 9 & linear* & 0.008 & -0.012 & \\
\hline$R t$ & - & - & 6 & - & & & \\
\hline Gl & - & - & 6 & - & & & \\
\hline$U r$ & 101 & ns & 12 & ns & & & 0.335 \\
\hline Mo & 124 & 0.94 & 9 & linear* & 0.100 & -0.634 & \\
\hline
\end{tabular}


Table 5. Regression of temperature $\left(\mathrm{T},{ }^{\circ} \mathrm{C}\right)$ versus respiration rates $\left(\mathrm{Resp}, \mathrm{gO}_{2} \cdot \mathrm{gDW}^{-1} \cdot \mathrm{d}^{-1}\right)$ for the ten selected species. Linear $(\operatorname{Re} s p=a T+b)$ and exponential $\left(\operatorname{Re} s p=a \times e^{b T}\right)$ regressions were tested for each species. The $\mathrm{a}$ and $\mathrm{b}$ values for the best regression coefficient $\left(\mathrm{R}^{2}\right)$ are shown. For not significant regressions, the mean $\overline{\mathrm{Resp}}$ value is reported and used in the model.

\begin{tabular}{|c|c|c|c|c|c|c|}
\hline & $\mathrm{R}^{2}$ & $\mathrm{n}$ & type & $\mathrm{a}$ & $\mathrm{b}$ & $\overline{\operatorname{Resp}}$ \\
\hline $\mathrm{Hi}$ & 0.98 & 9 & linear* & 0.008 & -0.052 & \\
\hline $\mathrm{Zm}$ leaves & 0.98 & 12 & exponential & 0.004 & 0.161 & \\
\hline $\mathrm{Zm}$ rhizomes/roots & 0.99 & 12 & exponential & 0.001 & 0.200 & \\
\hline $\mathrm{Zn}$ leaves & 0.91 & 12 & exponential & 0.019 & 0.042 & \\
\hline $\mathrm{Zn}$ rhizomes/roots & 0.92 & 12 & exponential & 0.005 & 0.045 & \\
\hline Gc & $\mathrm{ns}$ & 12 & ns & & & 0.060 \\
\hline $\mathrm{Cl}$ & 0.97 & 12 & exponential & 0.005 & 0.163 & \\
\hline$G d$ & 0.99 & 9 & exponential & 0.003 & 0.183 & \\
\hline$R t$ & - & 6 & - & & & \\
\hline$G l$ & - & 6 & - & & & \\
\hline$U r$ & ns & 12 & ns & & & 0.049 \\
\hline Mo & 0.97 & 9 & linear* & 0.026 & -0.197 & \\
\hline
\end{tabular}


Table 6. Annual mean carbon:nitrogen values $\left(\overline{\mathrm{CN}} \pm 95 \%\right.$ confidence limit, $\left.\mathrm{gC}_{\mathrm{gN}}{ }^{-1}\right)$ for each selected species (after Plus, 2001).

\begin{tabular}{|c|c|c|c|}
\hline & $\overline{\mathrm{CN}}$ & & $\mathrm{n}$ \\
\hline $\mathrm{Hi}$ & 13.7 & \pm 1.7 & 9 \\
\hline $\mathrm{Zm}$ leaves & 17.0 & \pm 2.2 & 12 \\
\hline$Z m$ rhizomes/roots & 35.4 & \pm 7.1 & 12 \\
\hline Zn leaves & 17.1 & \pm 1.0 & 12 \\
\hline Zn rhizomes/roots & 35.6 & \pm 4.3 & 12 \\
\hline Gc & 21.4 & \pm 7.0 & 9 \\
\hline $\mathrm{Cl}$ & 17.2 & \pm 2.2 & 12 \\
\hline$G d$ & 12.3 & \pm 1.9 & 9 \\
\hline$R t$ & 26.7 & \pm 7.5 & 9 \\
\hline$G l$ & 25.1 & \pm 7.2 & 6 \\
\hline$U r$ & 21.0 & \pm 3.4 & 15 \\
\hline Mo & 13.6 & \pm 2.4 & 15 \\
\hline
\end{tabular}

$\mathrm{n}:$ number of data. 
Table 7. Nutrients (ammonium and nitrate, in mmolN.m ${ }^{-3}$ ) and oxygen (mg. $\left.1^{-1}\right)$ concentrations in the ten rivers of the catchment and the Mediterranean seawater.

\begin{tabular}{lcccl}
\hline & $\mathrm{NH}_{4}^{+}$ & $\mathrm{NO}_{3}^{-}$ & $\mathrm{O}_{2}$ & References \\
Rivers: & & & & Anonymous (1997) \\
Vène & 25.0 & 54 & 9 & \\
Pallas & 40.0 & 85 & 9 & \\
Aiguilles & 40.0 & 85 & 9 & \\
Joncas & 40.0 & 85 & 9 & \\
Sesquier & 1.4 & 56 & 9 & \\
Aygues vaques & 2.8 & 199 & 9 & \\
Nègue vaques & 2.6 & 199 & 9 & \\
Mayroual & 5.8 & 198 & 9 & \\
Soupié & 51.0 & 195 & 9 & \\
Fontanilles & 5.8 & 198 & 9 & \\
\hline Seawater & 0.5 & 2 & 9 & Souchu et al. (1997) and Anonymous \\
& & & &
\end{tabular}


Table 8. Measured and simulated concentrations of ammonium $\left(\mathrm{NH}_{4}^{+}, \mathrm{mmol} \mathrm{N} . \mathrm{m}^{-3}\right)$ and detrital nitrogen (Ndet, $\mu$ g N.g dry sed. ${ }^{-1}$ ) in Thau lagoon sediments. Mean concentrations are given with minima and maxima in brackets.

\begin{tabular}{|c|c|c|c|c|}
\hline & \multicolumn{2}{|c|}{$\mathrm{NH}_{4}^{+}$} & \multicolumn{2}{|c|}{ Ndet } \\
\hline & winter & summer & winter & summer \\
\hline (1) & $123(100-150)$ & $60(40-80)$ & & \\
\hline (2) & $50(33-61)$ & $348(119-537)$ & & $(64-1280)$ \\
\hline (3) annual means & \multicolumn{2}{|c|}{$280(30-959)$} & \multicolumn{2}{|c|}{$(24-1799)$} \\
\hline Model results ( $\left.\mathrm{Mac}^{-}\right)$ & $283(227-438)$ & $673(440-1072)$ & $50(48-50)$ & $27(19-31)$ \\
\hline Model results $\left(\mathrm{Mac}^{+}\right)$ & $249(48-442)$ & $613(8-1828)$ & $52(48-60)$ & $52(20-142)$ \\
\hline
\end{tabular}

(1) Mesnage (1994); (2) Deslous-Paoli (1995); (3) Laugier et al. (1999) 
Table 9: Annual gross production (GP) of principal macrophyte species and phytoplankton simulated by the model for 1996 . 'Standard', $+10 \%$ and $-10 \%$ refer to the simulation runs defined in the text. For phytoplankton, transformations to nitrogen have been made using a $\mathrm{C}: \mathrm{N}$ ratio of $6.6 \mathrm{gC} \cdot \mathrm{gN}^{-1}$ (Redfield et al., 1963).

\begin{tabular}{|c|c|c|c|c|c|}
\hline \multirow[t]{2}{*}{ Species } & \multirow[t]{2}{*}{ Covered area $\left(\mathrm{km}^{2}\right)$} & \multicolumn{3}{|c|}{ GP (tons C.y ${ }^{-1}$ ) } & \multirow{2}{*}{$\begin{array}{l}\text { GP (tons N.y }{ }^{-1} \text { ) } \\
\text { Standard }\end{array}$} \\
\hline & & Standard & $-10 \%$ & $+10 \%$ & \\
\hline $\mathrm{Hi}$ & 10.2 & 5540 & 5124 & 5892 & 403 \\
\hline $\mathrm{Zm}$ & 23.5 & 10200 & 9363 & 10978 & 599 \\
\hline $\mathrm{Zn}$ & 9.8 & 6103 & 5752 & 6464 & 357 \\
\hline Gc & 17.1 & 752 & 699 & 807 & 35 \\
\hline $\mathrm{Cl}$ & 10.9 & 1327 & 1203 & 1448 & 77 \\
\hline$G d$ & 10.9 & 311 & 282 & 340 & 25 \\
\hline$G l$ & 17.1 & 319 & 300 & 340 & 13 \\
\hline$R t$ & 10.2 & 530 & 490 & 568 & 20 \\
\hline$U r$ & 6.2 & 504 & 464 & 541 & 24 \\
\hline Mo & 6.2 & 1726 & 1619 & 1823 & 127 \\
\hline Macrophytes & & 27312 & 25296 & 29200 & 1680 \\
\hline Phytoplankton & & 28652 & 27968 & 28707 & 4325 \\
\hline
\end{tabular}


Table 10. Comparison of primary producers gross production (expressed in $\mathrm{gC} \cdot \mathrm{m}^{-2} \cdot \mathrm{y}^{-1}$ ) for some temperate lagoons. Main characteristics of the lagoons are given: mean light extinction coefficient $\left(\mathrm{K}_{\text {ext }}\right)$, mean annual nitrogen load $\left(\mathrm{N}_{\text {load }}\right)$ and water turnover $(\mathrm{R})$. The row "Total" express the overall gross production for the lagoon considered

\begin{tabular}{|c|c|c|c|c|}
\hline & Bassin & Lake & Venice lagoon & Thau lagoon $^{(3)}$ \\
\hline & $\mathrm{d}^{\prime}$ Arcachon $^{(1)}$ & Grevelingen ${ }^{(2)}$ & & \\
\hline Surface $\left(\mathrm{km}^{2}\right)$ & 156 & 108 & 549 & 70 \\
\hline $\mathrm{K}_{\mathrm{ext}}\left(\mathrm{m}^{-1}\right)$ & - & $0.2-0.5^{(5)}$ & $1.3-8.6^{(6)}$ & $0.4^{(9)}$ \\
\hline $\mathrm{N}_{\text {load }}\left(\right.$ tons. $\left.^{-1}\right)$ & $1441-1555^{(4)}$ & $432^{(5)}$ & $6900^{(7)}$ & $240^{(9)}$ \\
\hline $\mathrm{R}$ & $8-43$ hours $^{(4)}$ & $6-12$ months $^{(5)}$ & 20 hours $^{(8)}$ & $1-5$ months $^{(9)}$ \\
\hline phytoplankton & 23 & $60-225$ & - & 410 \\
\hline microphytobenthos & $31-79$ & $32-35$ & - & - \\
\hline seagrasses & $160-219$ & 162 & $165^{(10)}$ & $430-630$ \\
\hline other macrophytes & - & - & - & $20-540$ \\
\hline Total $\left(\mathrm{tC} \cdot \mathrm{y}^{-1}\right)$ & $22256-33621$ & $16431-37575$ & $30316-40421^{(11)}$ & 55964 \\
\hline \multicolumn{5}{|c|}{$\begin{array}{l}\text { (1) Auby et al. (1993), }{ }^{(2)} \text { Nienhuis and De Bree (1980) and Vegter and De Vissher (1984), in } \\
\text { Auby (1991), }{ }^{(3)} \text { present study, }{ }^{(4)} \text { Auby et al. (1994), }{ }^{(5)} \text { Nienhuis (1992), }{ }^{(6)} \text { Rigollet et al. } \\
(1998),{ }^{(7)} \text { Coffaro and Bocci }(1997),{ }^{(8)} \text { Sfriso and Marcomini (1996), }{ }^{(9)} \text { Anonymous (1997), } \\
(10) \text { only Z. marina, Rismondo et al. (1995), }{ }^{(11)} \text { estimated only for the central part of the } \\
\text { lagoon }\left(85 \mathrm{~km}^{2}\right) \text { by Sfriso et al. (1989). }\end{array}$} \\
\hline
\end{tabular}




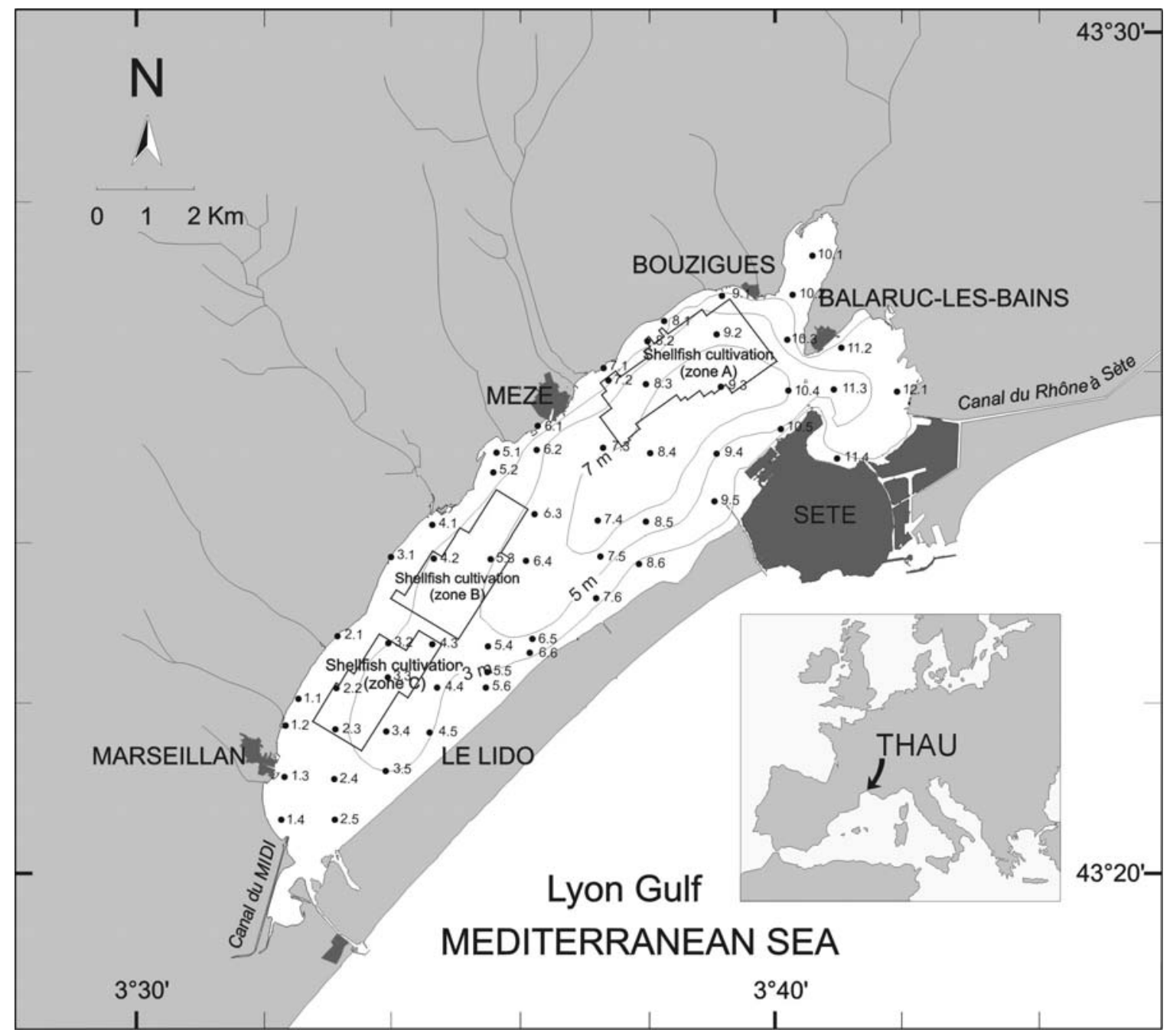

Figure 1. The Thau lagoon and its watershed. Connections with the Mediterranean Sea are located at the extremities: in the Sète city and near Marseillan village. Black points represent the evenly distributed stations sampled during the PNEC campaign. 


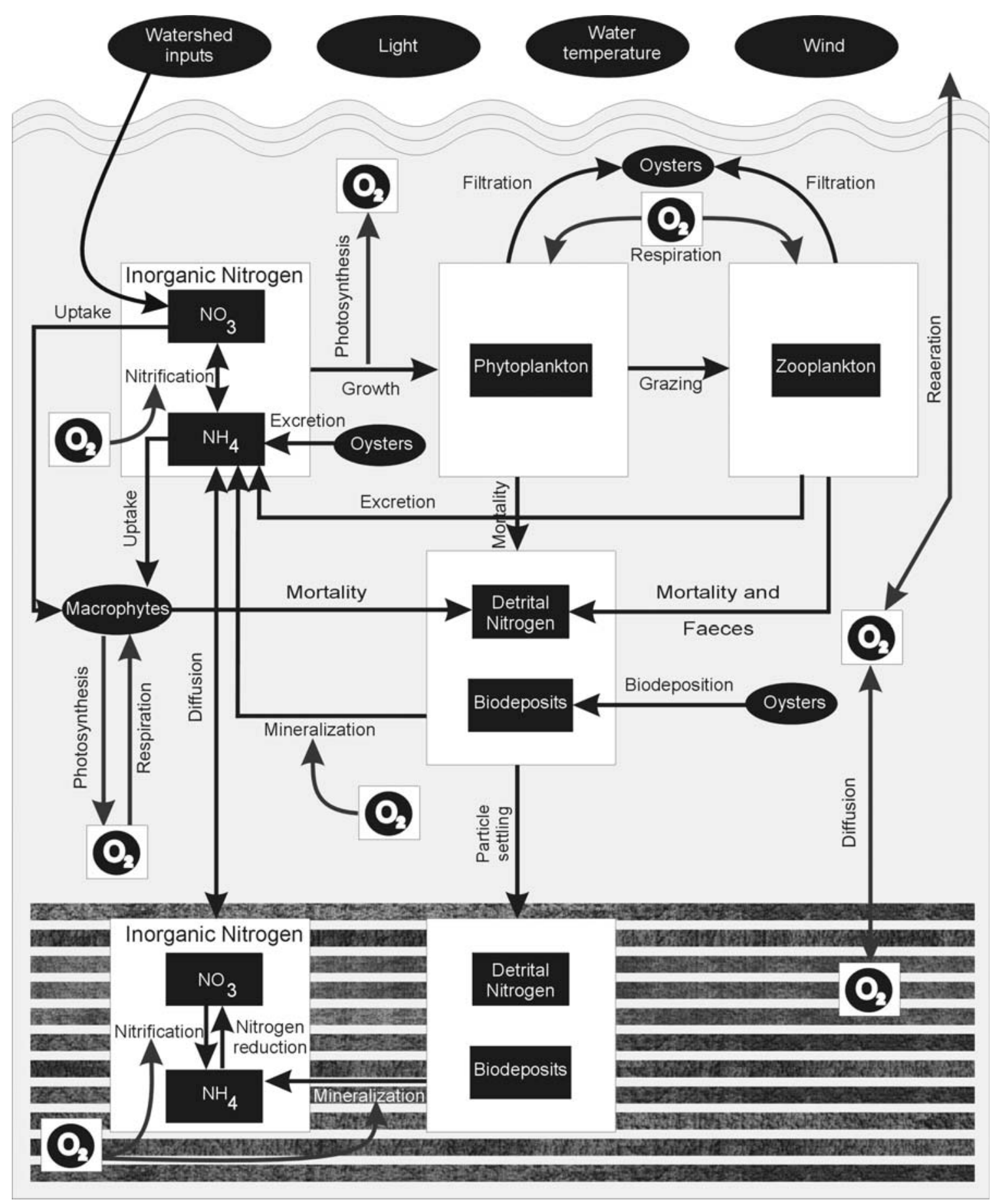

Figure 2. Conceptual diagram of the biological model (after Chapelle et al., 2000). White rectangles means state variables while black ellipses are forcing variables. 


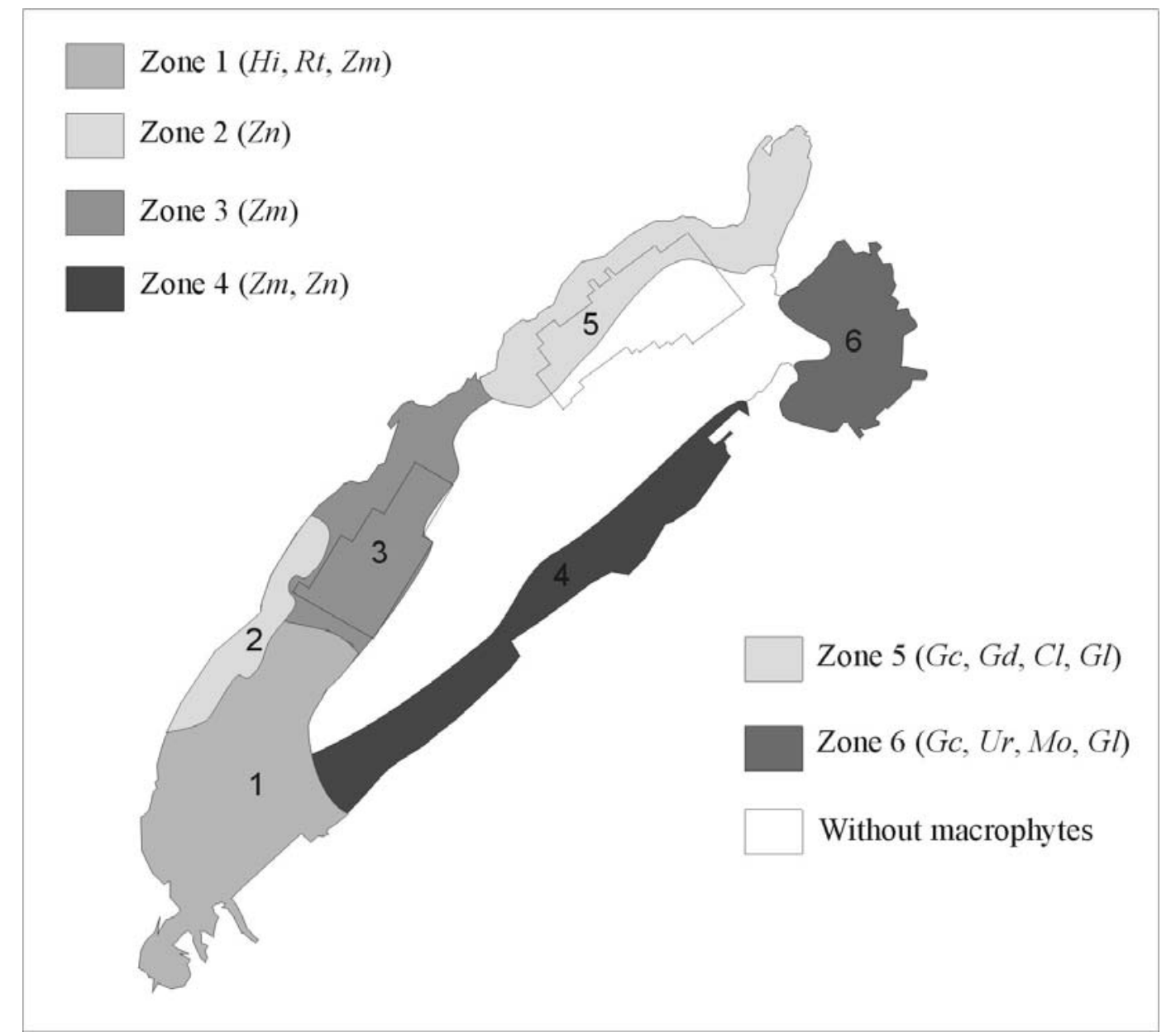

Figure 3. Simplified macrophyte mapping which resulted from the CA analysis. For each zone, characteristic species are given in brackets. Labels as in Table 2. 

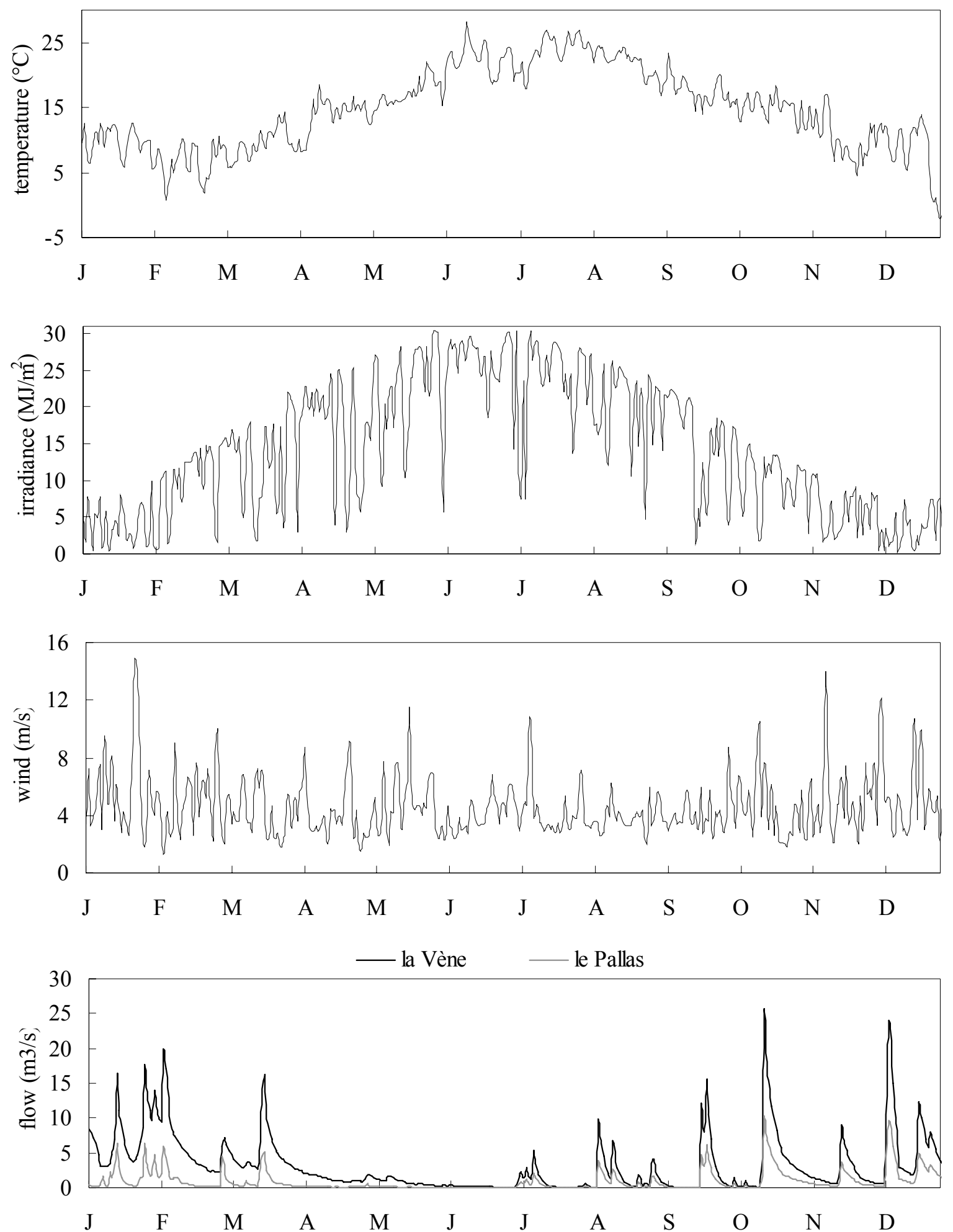

Figure 4. Meteorological forcing data used in the model for year 1996: air temperature, irradiance, wind speed and flows of the two main rivers in Thau lagoon catchment area. 


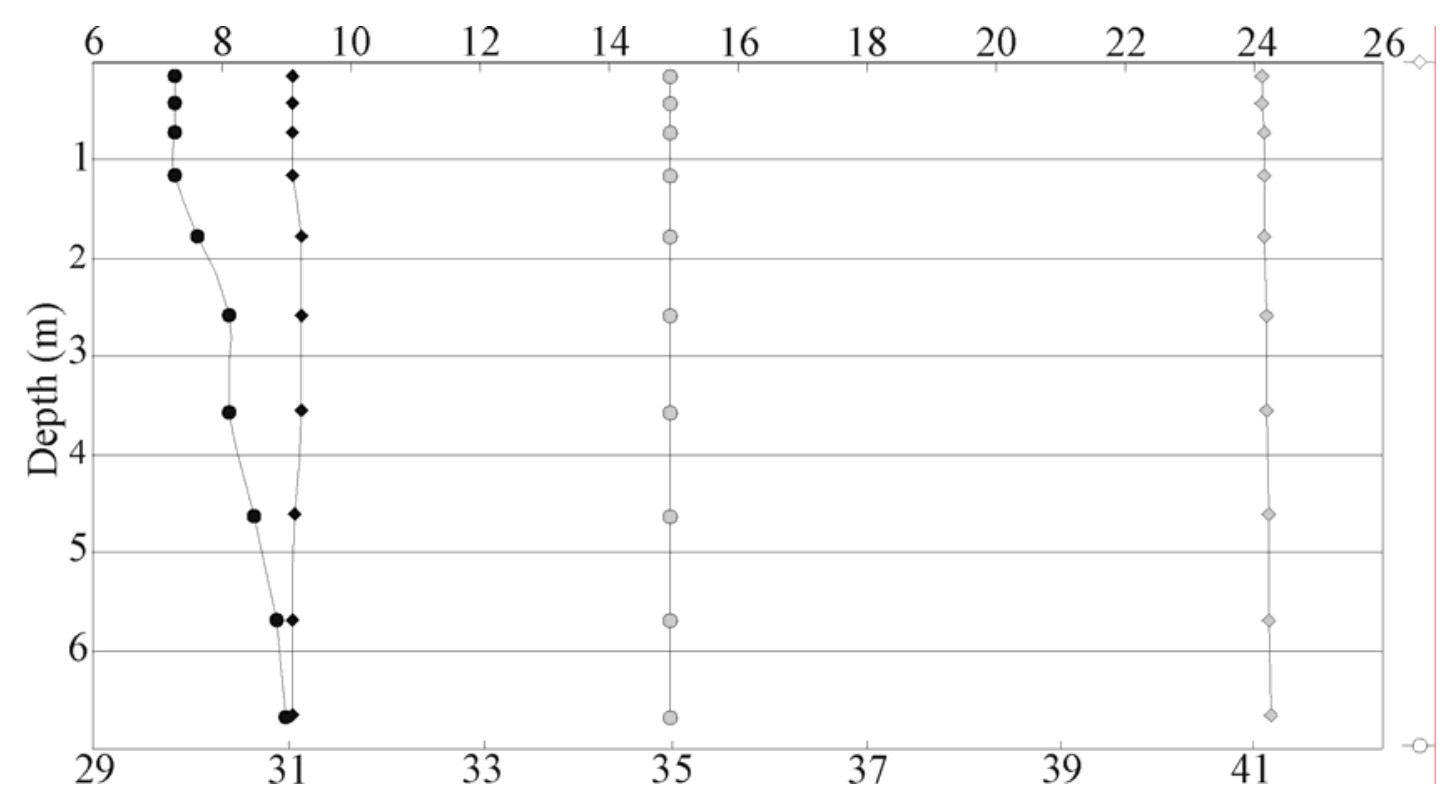

Figure 5. Temperature (rhombus, ${ }^{\circ} \mathrm{C}$ ) - salinity (circles) diagram. Model simulations for the 31 January 1996 (in black) and the 30 June 1996 (in grey), at station 7.3 (centre of the lagoon). Salinity scale is on the bottom and temperature scale on the top of the diagram. 


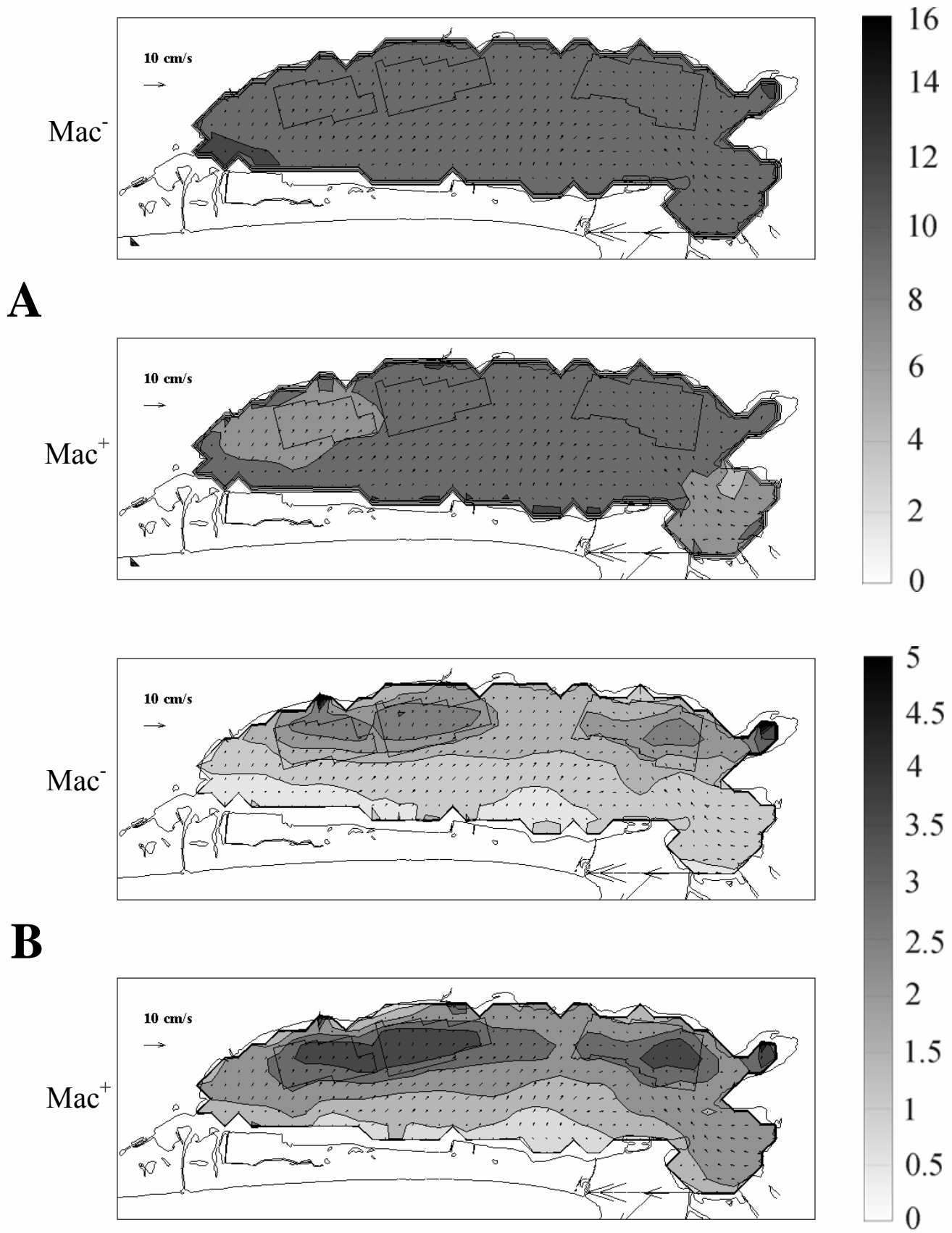

Figure 6. Simulation results at the 31 January 1996. Variables presented are: A) dissolved oxygen concentrations (mg. $\mathrm{l}^{-1}$ ) and B) ammonium concentrations $\left(\mathrm{mmol} \cdot \mathrm{m}^{-3}\right)$. Both simulations with ( $\left.\mathrm{Mac}^{+}\right)$and without macrophytes ( $\left.\mathrm{Mac}^{-}\right)$are presented for bottom waters. 

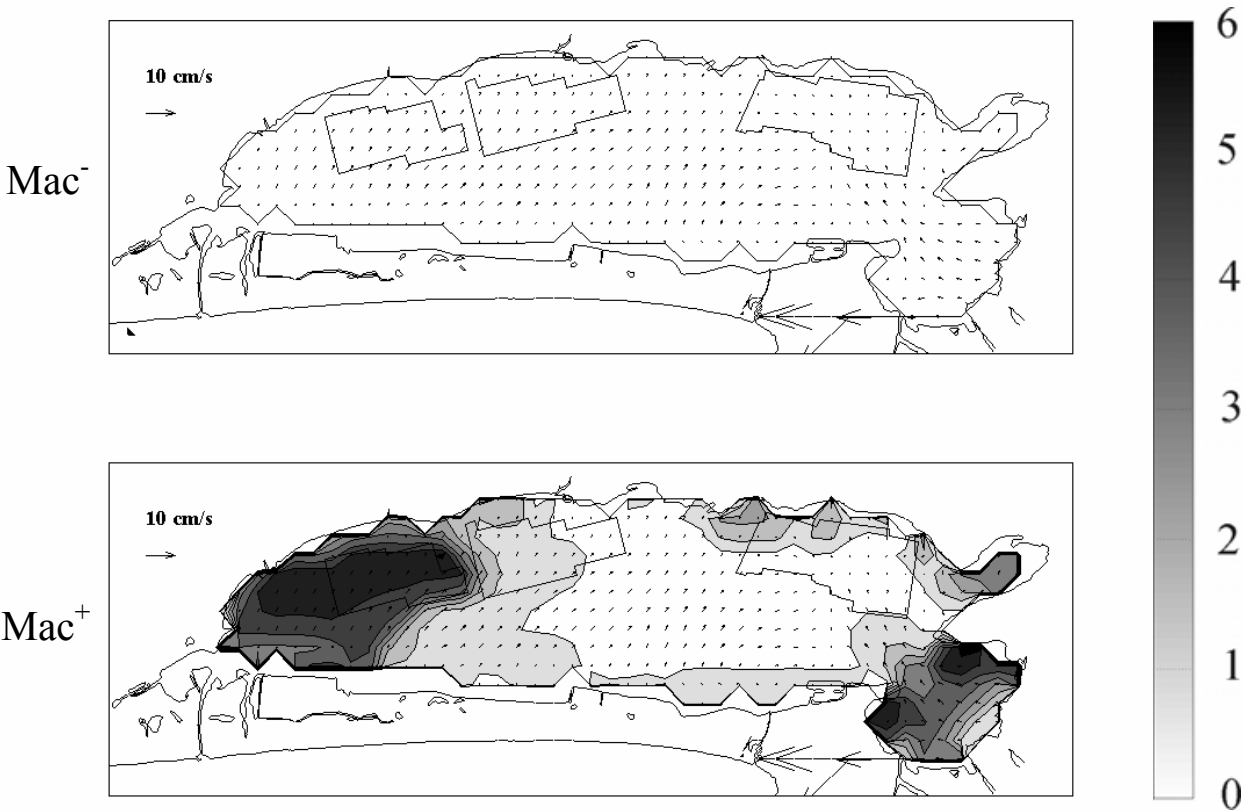

B
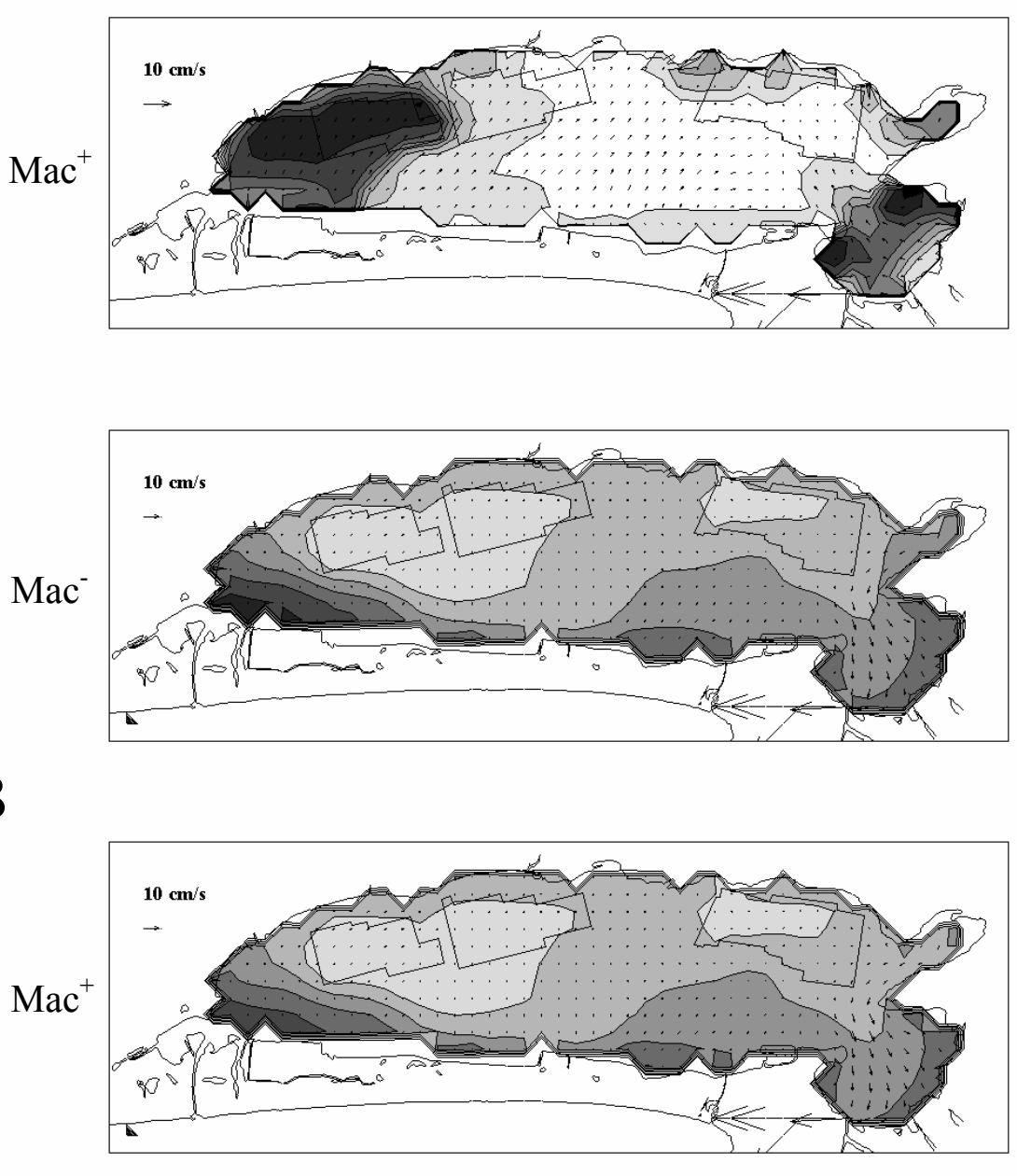

3

2

8

6

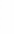

4

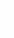

(

4

2

0

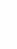

6

4

2

0

Figure 7. Simulation results at the 31 January 1996. Variables presented are: A) detrital nitrogen concentrations $\left(\mathrm{mmol} . \mathrm{m}^{-3}\right)$ and B) phytoplankton biomass $\left(\mathrm{mmol} \mathrm{N} . \mathrm{m}^{-3}\right)$ in the water column. Concentrations are presented for bottom waters in A and for surface waters in B. 

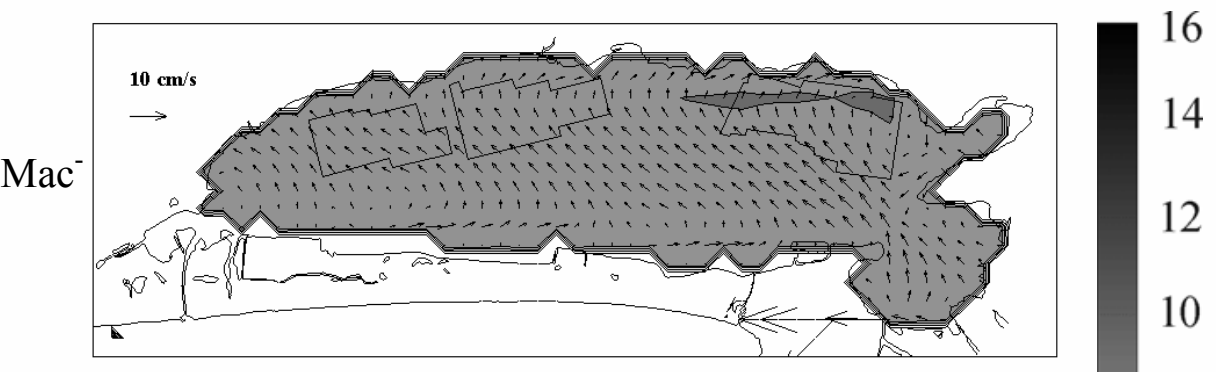

A
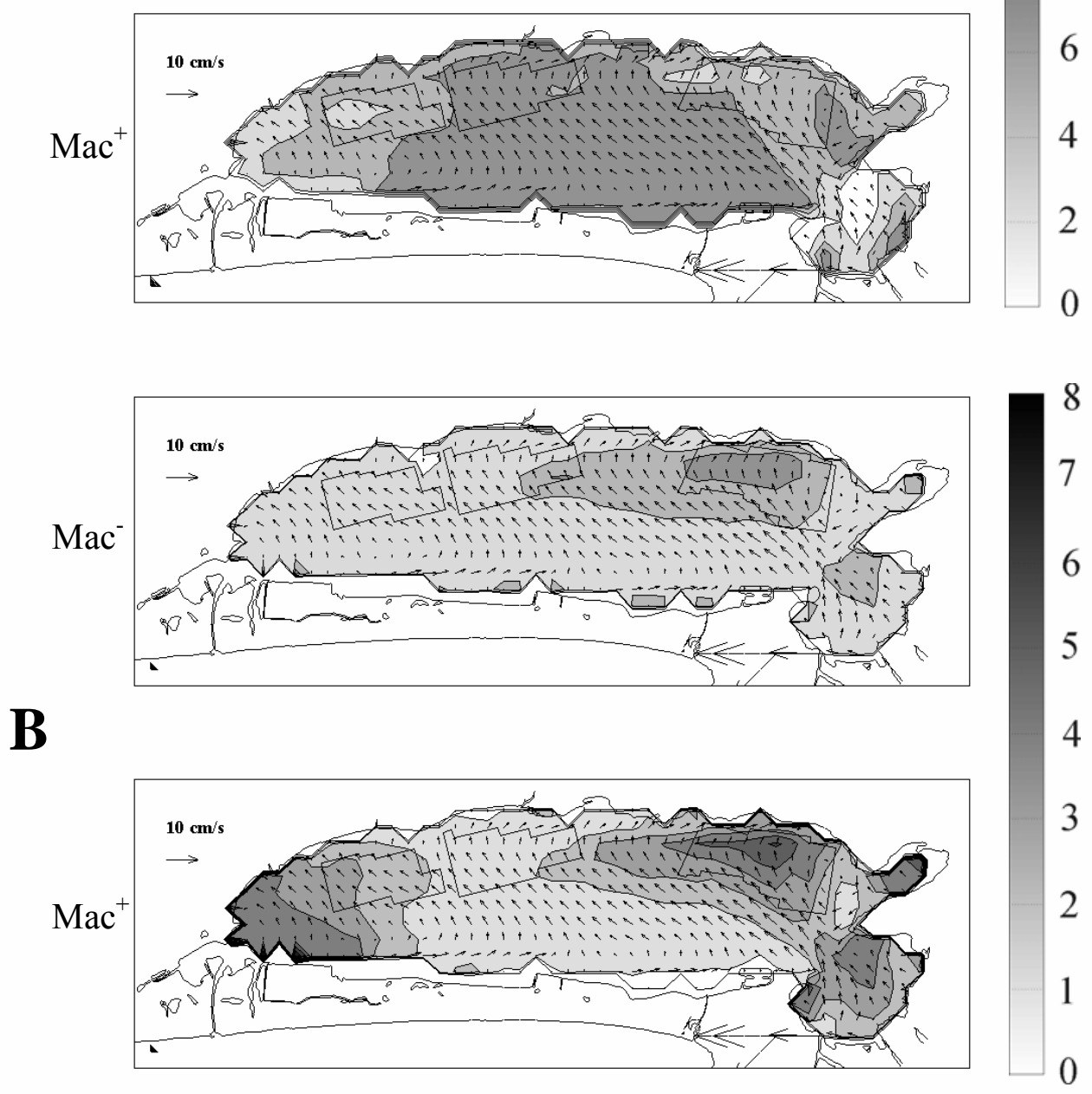

Figure 8. Simulation results at the 30 June 1996. Variables presented are: A) dissolved oxygen concentrations (mg. $\left.\mathrm{l}^{-1}\right)$ and B) ammonium concentration $\left(\mathrm{mmol} \cdot \mathrm{m}^{-3}\right)$. Concentrations are presented for bottom waters. 

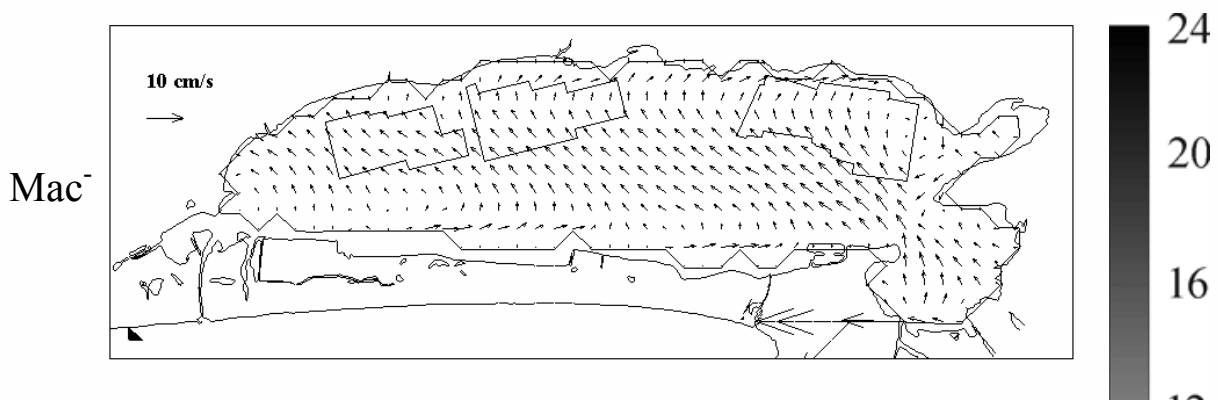

A
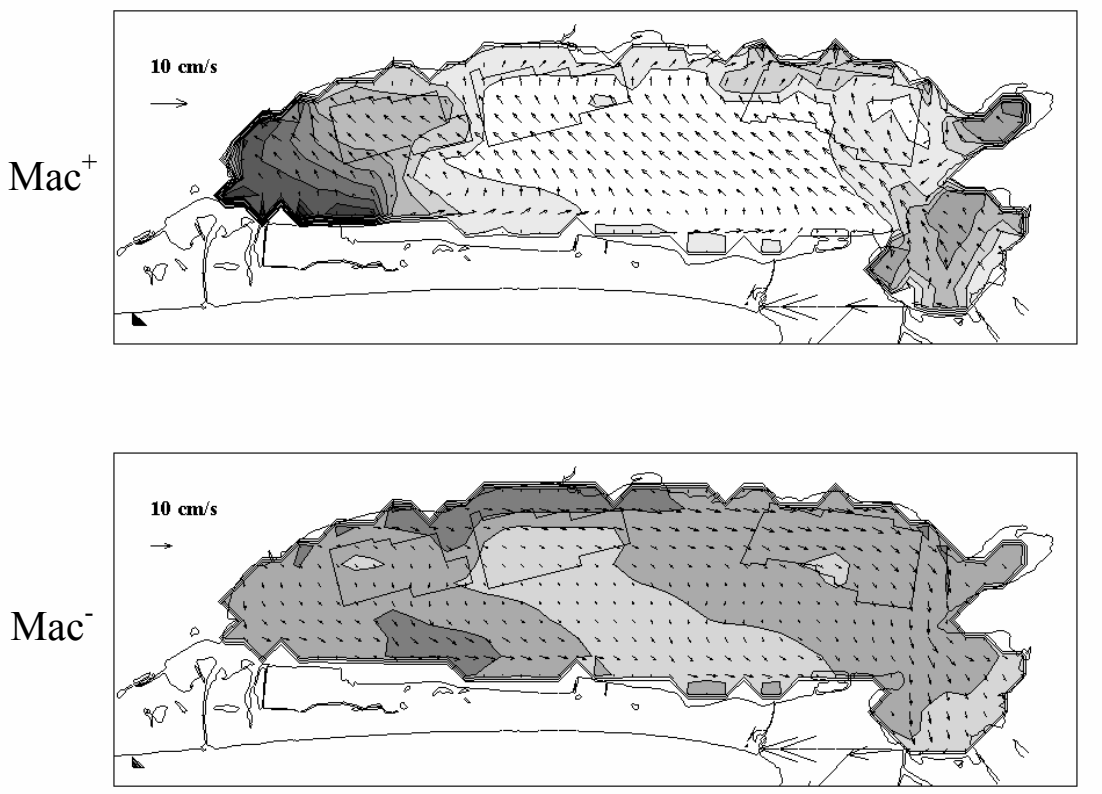

B

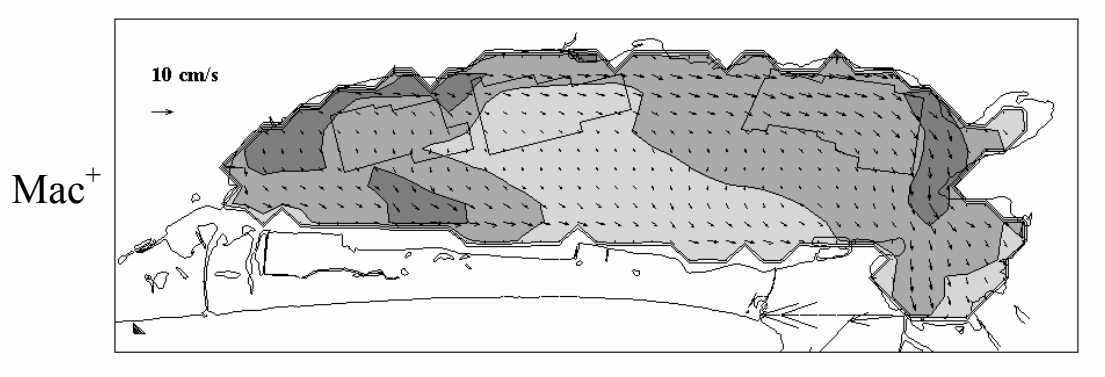

Figure 9. Simulation results at the 30 June 1996. Variables presented are: A) detrital nitrogen concentrations $\left(\mathrm{mmol} . \mathrm{m}^{-3}\right)$ and B) phytoplankton biomass $\left(\mathrm{mmol} \mathrm{N} . \mathrm{m}^{-3}\right)$. Simulations are presented for bottom waters in A and for surface waters in B. 